\title{
Diet is correlated with otolith shape in marine fish
}

\author{
Mille Tiphaine ${ }^{1,{ }^{*}}$, Mahe Kelig ${ }^{1}$, Cachera Marie ${ }^{2}$, Villanueva Ching-Maria ${ }^{3}$, De Pontual Helene ${ }^{3}$, \\ Ernande Bruno ${ }^{1}$
}

${ }^{1}$ Ifremer, Centre Manche Mer du Nord, Laboratoire ressources halieutiques, BP 699, 62321 Boulogne-

sur-mer, France

${ }^{2}$ Laboratoire des Sciences de l'Environnement Marin, UMR 6539, Institut Universitaire Européen de la

Mer, 29280 Plouzané, France

${ }^{3}$ IFREMER, Centre de Bretagne, Unité Sciences et Technologies Halieutiques, Z.I. Pointe du Diable, CS10070, 29280 Plouzané, France

* Corresponding author : Tiphaine Mille, email address : tiphaine.mille@ifremer.fr

\begin{abstract}
:
Previous studies have shown that food amount influence fish otolith structure, opacity and shape and that diet composition has an effect on otolith chemical composition. This study investigated the potential correlation between diet and otolith shape in 5 wild marine fish species by addressing 4 complementary questions. First, is there a global relationship between diet and otolith shape? Second, which prey categories are involved in this relationship? Third, what are the respective contributions of food quantity and relative composition to diet-otolith shape co-variation? Fourth, is diet energetic composition related to otolith shape? For each species, we investigated how otolith shape varies with diet. These questions were tackled by describing diet in the analysis in 4 different ways, while also including individual-state variables to remove potential confounding effects. First, besides the strong effect of individual-state, a global relationship between diet and otolith shape was detected for 4 out of 5 fish species. Second, both main and secondary prey categories were related to variability in otolith shape. Otolith outline reconstructions revealed that both otolith global shape and its finer details co-varied with these prey categories. Third, the contribution of relative diet composition to diet-otolith shape co-variation was much higher than that of ingested food quantity. Fourth, the energetic composition of diet was related to otolith shape of only one species. These results suggest that diet in marine fish species may influence the quantity and composition of saccular endolymph proteins which play an important role in otolith biomineralization and their resulting 3D structure.
\end{abstract}

Keywords : Ellipitic Fourier analysis, English Channel, Interspecific, Morphometric analysis, Otolith growth, Saccular otolith, Stomach contents 


\section{$\underline{\text { Introduction }}$}

Otoliths are calcified structures found in the inner ear of teleostean fish. They are organised into 3 pairs and assist with auditory and balance functions of fish. They are critical tools in fisheries science and management. Their structure allows aging individual fish and determining population age structure for stock assessment (e.g. Worthington et al. 1995, Caldow \& Wellington 2003). Their morphology can be used for individual assignment to (sub)populations and to infer population structure (e.g. Castonguay et al. 1991, Stransky et al. 2008). The sagittae (the most studied otolith pair because of their large size) are mainly composed of calcium carbonate in aragonite form deposited on an organic matrix which represents 0.1 to $10 \%$ of total material (Degens et al. 1969). The organic matrix, although present in minute amounts in otoliths, is thought to play a key role in its formation as in all biomineralization processes (Nagasawa 2013). Biomineralization of the sagittal otolith (referred to as "otolith" hereafter) is an acellular process that takes place in the saccule (otic sac). Otoliths grow by accretion and precipitation of organic and ionic precursors contained in the saccular endolymph in which they are bathing. Otolith biomineralization is therefore totally dependent on the endolymph composition and precursors that are either synthesized (organic) or transported (ionic) by secretory cells and ionocytes, respectively, belonging to the saccular epithelium (Payan et al. 2004). Moreover, the spatial distribution of these cells in the saccular epithelium induces concentration gradients of both ions and organic precursors in the endolymph that are involved in otolith biomineralization processes (Pisam et al. 1998, Payan et al. 1999, Borelli et al. 2001).

Otolith biomineralization results from multi-causal processes due to the interaction of many internal (physiological) and external (environmental) factors (Allemand et al. 2007), which generates high morphological variability in otolith shape at both intra- and inter-specific level. 
First, otolith shape is species-specific (Tuset et al. 2006), reflecting genetic determinism (L’Abée-Lund 1988, Vignon \& Morat 2010).

Second, factors or processes acting on fish metabolism and physiology have an impact on otolith morphology, such as ontogenetic development (size: Hüssy, 2008 and age: Castonguay et al. 1991, sexual maturation (Mérigot et al. 2007) or sex (Castonguay et al. 1991, Bolles \& Begg 2000). Third, environmental factors such as water temperature produce otolith growth variation and thus shape variability (Cardinale et al. 2004). Food quantity can also impacts otolith shape both directly and indirectly. It has an indirect effect on global otolith shape through its effect on otolith growth and a direct effect on otolith crenation (Gagliano \& McCormick 2004, Cardinale et al. 2004, Hüssy 2008).

Consequences of fish nutrition on otolith structure and growth, especially the impact of starvation or food restriction and satiation, have been well studied (Molony \& Choat 1990, Molony \& Sheaves 1998, Hüssy \& Mosegaard 2004, Fernandez-Jover \& Sanchez-Jerez 2015). A decrease in the otolith increments' width and thus in otolith growth was observed after reduced feeding periods (Massou et al. 2002). More translucent otolith material is deposited in response to severe (long period and low ration) food restriction, which can lead to otolith structural discontinuities that do not conform to the seasonal opaque and translucent layers of annuli (Høie et al. 2008), referred to as "checks" (Panfili et al. 2002). Such changes in opacity are the consequences of variation in the composition of inorganic and organic otolith compounds (Jolivet et al. 2013) and precursors. A starvation period leads to change in blood plasma composition, which generates a decrease in the acid-base equilibrium in the saccular endolymph and thus, induces a reduction of aragonite precipitation rate. As a consequence, a reduction of daily growth rate due to starvation could be observed even if calcium concentration was not affected (Payan et al. 1998). Concerning the organic precursors, only the protein «Factor Retarding Crystallization» (FRC) concentration decreases during starvation periods 
especially in the proximal zone (Guibbolini et al. 2006). This change may play a key role in the intensity of aragonite deposition and thus otolith growth. In conclusion, food amounts may affect otolith growth, opacity (or structure) and biomineralization.

Several papers have also documented a link between energy metabolism and otolith growth. Otolith growth is closely related to standard metabolic rate (Mosegaard et al. 1988, Fablet et al. 2011) and otolith accretion appears regulated by feeding-induced thermogenesis (Huuskonen \& Karjalainen 1998). Otolith growth in larvae and juveniles is also related to individuals' condition index estimated from fish lipid composition (Amara et al. 2007), which in turn depends on zooplankton biomass (Suthers et al. 1992). Besides the fact that lipid quantity such as triacylglycerol content can be used as a condition index for fish (Fraser 1989), taken together these results suggest that lipid content in diet and energy metabolism may influence otolith growth. Given that lipid content of prey is the primary determinant of their energy density (Anthony et al. 2000, Spitz et al. 2010), diet energy content or composition in terms of energetic prey categories is a good candidate for encompassing both effects.

Along with food abundance and energy content, diet composition can also affect otoliths, especially their chemical composition (Sanchez-Jerez et al. 2002). For instance, Barium (Ba) and strontium ( $\mathrm{Sr}$ ) concentrations in Pomatomus saltatrix otoliths were related to the concentration of these elements in their prey (Buckel et al. 2004). Here, the authors assumed the diet effect on $\mathrm{Ba}$ and $\mathrm{Sr}$ concentration in otoliths could be either direct or indirect through diet-based growth rate changes that induce element incorporation rate variation in otoliths. Even if around $80 \%$ of $\mathrm{Sr}$ and $\mathrm{Ba}$ in otoliths come from water (Walther \& Thorrold 2006) and not from diet, a trophic transfer may be considered as a potential source of element accumulation in fish otolith. The concentration of manganese $(\mathrm{Mn})$ in the habitat and prey items was also related to its accumulation in otoliths (Sanchez-Jerez et al. 2002). The fact that the Mn:Ca ratio in otoliths is not correlated to the same ratio in water suggests a trophic transfer of metallic 
elements, such as Mn (Thorrold et al. 1997). Moreover, variations in $\delta^{13} \mathrm{C}$ otolith values were observed to correlate with variations in muscular $\delta^{13} \mathrm{C}$ values among diet treatment (Elsdon et al. 2010).

In summary, previous experimental work revealed that the food ration level affects otolith structure, opacity and shape. Laboratory and wild conditions studies have shown that energy metabolism and food energy content influences otolith growth and that diet composition impacts otolith chemical composition. In the present study, we investigated the potential relationship between diet, described as a combination of both food composition and quantity, and the otolith shape at the intra-population level in five marine fish species, including three roundfishes and two flatfish sampled in the wild. More specifically, we addressed four related questions. We first tested for a global relationship between diet (represented by the weight of each taxonomic prey category) and otolith shape. Second, in case of significant diet effect, taxonomic prey categories involved in the relationship with otolith shape were identified. Third, we quantified the respective contributions of food quantity and taxonomic composition to dietotolith shape co-variation. Fourth, we tested for the relationship between diet composition in terms of energetic prey categories and otolith shape. For all questions, the effect of potential confounding factors, i.e. individual-state variables (age, length, sex and maturity status), on otolith shape was quantified and removed to obtain unbiased estimates of food effects.

\section{$\underline{\text { Materials and methods }}$}

\section{$\underline{\text { Sample collection }}$}

Five marine fish, three roundfishes and two dextral flatfishes, were sampled in the eastern English Channel (Fig. 1) : 47 striped red mullets (Mullus surmuletus), 28 tub gurnards (Chelidonichthys lucerna), 32 red gurnards (helidonichthys cuculus) and 42 European plaices

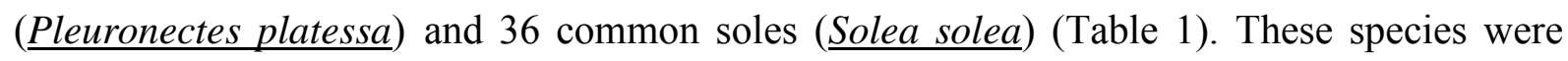


chosen because of their commercial interest, of their large sample size, they represent a combination of round and flat fish, and they are among the most abundant ones in the area. For each species, individuals sampled belonged to a single population for each species. All fish were caught during the annual Channel Ground Fish Survey (CGFS) operated on board the R.V. "Gwen Drez" in October 2009. The fishing gear was a Grande Ouverture Verticale bottom trawl with a 10-mm stretched mesh size in the codend, that was towed for $30 \mathrm{~min}$ at an average speed of 3.5 knot (Coppin et al. 2002). Following their capture, fish were identified at the specific level and sampled individuals were frozen in liquid nitrogen for their conservation on board.

Back in the laboratory, individuals were defrosted, measured (total length, $L_{\mathrm{T}}$ ) to the nearest centimeter and their sex and maturity status were determined by gonads macroscopic observation according to the recommendations of international expert groups (ICES 2014). The digestive tract was extracted and its contents removed and stored in a Petri-dish for analysis. Sagittal otoliths were also removed from each individual, one of them being used to estimate the individual's age by interpreting macrostructures according to accepted standard ageing protocols (ICES 2010, 2012) and the second one for shape analysis, each of them coming always from the same side (Table 1). For striped red mullet, age was estimated by reading macrostructures on the sagittal otolith pair. The left otolith was read under transmitted light while the right one was read under reflected light before being burned to confirm the age estimation done previously (ICES 2012). The left otolith (not burned) was then used for shape analysis. Even though recommendations from ICES expert groups do not exist for tub and red gurnards, the same methods were effective when applied to these species. For European plaice, the entire left otolith was used to estimate age as well as for shape analysis (ICES 2010), whereas, for common sole, a transversal section of the left otolith was necessary for age reading (Mahé et al. 2012) so that the right otolith was used for shape analysis. 
172 Hereafter, we describe otolith shape analysis, diet analysis and statistical analyses as they were conducted for each species separately.

\section{$\underline{\text { Otolith shape analysis }}$}

Each otolith was cleaned by an ultrasonic bath in water at room temperature for a duration of 10 minutes, then brushed to remove residual tissues and stored dry in tubes. Batches of otoliths were automatically digitized using orthogonal projection at a high resolution (3200 dpi) using a scanner EPSON V750 and individual images were extracted. An Elliptical Fourier analysis was performed on each otolith contour delineated and extracted after image binarization. This method reconstructs any type of shape with a closed two dimensional contour (Kuhl \& Giardina 1982) using ellipses named harmonics. Each harmonic $\left(H_{i}\right)$ is characterized by 4 coefficients ( $A_{i}, B_{i}, C_{i}$ and $D_{i}$ ), called Elliptic Fourier Descriptors (EFDs), which correspond to the parameters of the trigonometric equations describing the corresponding ellipse. The number of harmonics $n$ used to reconstruct each otolith outline in the sample was determined as follows using the cumulated Fourier power $\left(\mathrm{P}_{\mathrm{F}}\left(n_{\mathrm{k}}\right)\right)$. This parameter was calculated for each otolith $k$ as the sum of the proportion of variation in contour coordinates accounted for by each harmonic and it is equal to:

$$
\mathrm{P}_{\mathrm{F}}\left(\mathrm{n}_{\mathrm{k}}\right)=\sum_{\mathrm{i}=\mathbf{1}}^{\mathrm{n}_{\mathrm{k}}} \frac{A_{\mathrm{i}}^{2}+B_{\mathrm{i}}^{2}+C_{\mathrm{i}}^{2}+D_{\mathrm{i}}^{2}}{2} .
$$

The number of harmonics $n_{k}$ was then chosen such that $\mathrm{P}_{\mathrm{F}}\left(n_{k}\right)$ reaches $99.99 \%$ of variation in contour coordinates or, in other words, such that shape is reconstructed at $99.99 \%$ (Lestrel 2008). A majority of studies (e.g. Mérigot et al. 2007, Lestrel 2008) compute the cumulated Fourier power $\mathrm{P}_{\mathrm{F}}$ using EFDs averaged across the full sample or part of it, so that the selected harmonics describe the average otolith shape. In this study, $\mathrm{P}_{\mathrm{F}}\left(n_{k}\right)$ and $n_{k}$ were calculated for 
each individual otolith $k$ in order to ensure that each individual otolith in the sample was reconstructed with a precision of $99.99 \%$ The maximum number of harmonics $n=\max _{k}\left(\mathrm{n}_{k}\right)$ across all otoliths was then used to reconstruct each individual otolith of the sample.

After extracting the $n$ harmonics for each individual otolith, their EFDs were normalized by the first harmonic providing EFDs invariant with respect to size, rotation and starting point (Kuhl \& Giardina 1982), and resulting in the degeneration of the first three EFDs $\left(A_{i}, B_{i}\right.$ and $C_{i}$ ), respectively equal to $1, \approx 0$ and $\approx 0$ for each individual. EFDs were then gathered in a matrix $\mathbf{F}$ with EFDs as columns and individuals as rows.

All otolith images and EFDs were obtained using the software TNPC 7.0 (www.tnpc.fr).

\section{$\underline{\text { Diet analysis }}$}

For each fish, taxonomic identification of prey items in the stomach content was carried out using a binocular loupe. Prey items were identified to the lowest possible taxonomic level before being weighed (g, wet weight). In view of their high diversity, preys were grouped into 22 taxonomic categories (Table S1 in Supplementary material) mostly based on their main taxonomic level. Preys were categorized at least according to their Phylum in the taxonomic hierarchy (e.g. annelida, cnidaria). If further taxonomic determination was possible, taxonomic prey categories were based on Class (e.g. cephalopoda, gastropoda), Order (e.g. amphipoda, isopoda) or Infra-Order (e.g. brachyoura, anomoura). Teleosts were split into two taxonomic prey categories depending on their energetic value. The energy content of each fish prey (found at http://www.nutraqua.com/) was plotted. Fish species gathered in two main groups (fat and lean) separated by a threshold of $1{\mathrm{kcal} . \mathrm{g}^{-1}}^{\text {. }}$

Alternatively, preys were regrouped into three categories based on their energetic content (low/medium/high; Table S1 and Fig. S3 in Supplementary material) estimated from appropriate literature (Norrbin \& Båmstedt 1984, Steimle \& Terranova 1985, Dauvin \& 
Joncourt 1989, Spitz et al. 2010) and following the three energetic categories proposed by Spitz et al. 2010.

For each studied species, stomach content data were grouped in a diet composition matrix in terms of weight, based either on taxonomic $\mathbf{W}_{t}$ or energetic prey categories $\mathbf{W}_{e}$, with each cell corresponding to the weight $w_{t, i j}$ or $w_{e, i j}$ of prey category $j$ (columns) in the digestive tract of individual $i$ (rows). In addition, the relative contribution of taxonomic prey categories to diet composition by weight $\left(\% W_{t, j}=\sum_{i} w_{t, i j} / \sum_{i} \sum_{j^{\prime}} w_{t, i j^{\prime}}\right)$ and the relative frequency of occurrence $\left(\% F_{t, j}\right)$ of each taxonomic prey category (Godfriaux 1969), were computed for each studied species (Fig.2).

\section{$\underline{\text { Statistical analyses }}$}

A principal component analysis (PCA) combined with broken stick principal component selection (Borcard et al. 2011, Chapter 5) was performed on the EFDs matrix F. The aim was to decrease the number of dimensions used to describe otolith shape variability while avoiding collinearity between them and ensuring that the main sources of shape variation were kept (Rohlf \& Archie 1984). The selected principal components were gathered to construct the otolith shape matrix $\mathbf{S}$ with principal components of EFDs as columns and individuals as rows. The otolith shape matrix $\mathbf{S}$ was modelled using redundancy analysis (RDA) as depending on three explanatory matrices: an individual matrix I grouping individual-state variables and a diet matrix $\mathbf{D}$ derived from the diet composition:

$$
\mathbf{S} \sim \mathbf{I}+\mathbf{D} .
$$

The matrix I was included in the model to disentangle and remove the effect of individualstate as possible confounding factors on otolith shape. It was composed of fish age $A$ as a factor and total length $L_{\mathbf{T}}$ as a continuous effect to represent the ontogenetic effect on otolith shape, 
sex $S_{\mathrm{e}}$ and maturity status $M$ of the individual as factors potentially affecting fish physiology and metabolism, and thus indirectly otolith biomineralization. The resulting model was:

$$
\mathrm{S} \sim A+L_{\mathbf{T}}+S_{\mathbf{e}}+M+\mathbf{D}
$$

Alternatively, the potential confounding effect of environmental factors was also accounted for by including an environmental matrix $\mathbf{E}$ grouping external environmental factors in model 2:

$$
\mathbf{S} \sim \mathbf{I}+\mathbf{E}+\mathbf{D}
$$

Matrix $\mathbf{E}$ contained four variables to describe environmental conditions that may also affect otolith biomineralization: temperature $T$ and salinity $S_{\mathrm{a}}$ that were extracted from the hydrodynamic model MARS 3D (Lazure \& Dumas 2008) and averaged over the month of October 2009, depth $D_{\mathbf{p}}$ that was measured at each sampling station during the survey, and longitude and latitude $\left(L_{\mathbf{0}} \times L_{\mathbf{a}}\right)$ of the sampling station. The resulting model was:

$$
\mathbf{S} \sim A+L_{\mathrm{T}}+S_{\mathrm{e}}+M+T+S_{\mathrm{a}}+D_{\mathrm{p}}+L_{\mathrm{o}} \times L_{\mathrm{a}} .
$$

The complete model described by Eq.3 (be it its version without $3 \mathrm{a}$ or with environmental variables $3 b$ ) was reduced by stepwise selection based on significance (p-values) of the effects determined by permutation tests (Borcard et al. 2011). Potential collinearity between explanatory variables was checked by computing their Variance Inflation Factors (VIF) before and after model reduction (Borcard et al. 2011). No strong collinearity (VIF $<10)$ was detected after mode reduction. Then, a variation partitioning was performed to estimate the percent contribution of the two (I and D) or three (I, E and D) reduced matrices to otolith shape variation. The strict contribution of each reduced matrix to variation was tested using partial redundancy analysis (pRDA) followed by a permutation tests, with the matrix for which the contribution was estimated as an explanatory matrix and the other matrix or matrices depending 
on model version ( $3 a$ or $3 b$ ) as covariables. Standard deviation was computed for all fractions of variation by bootstrapping. 500 bootstrap samples (random sampling with replacement) were enough to obtain stable standard deviation estimates in all cases.

In order to answer the four main questions of the study, the previously described analysis was performed with the diet matrix D constructed in four different ways (Fig. 3) as described below.

\section{Global relationship between diet and otolith shape (model 1, Fig. 3A)}

In order to estimate the potential global relationship between diet and otolith shape, matrix $\mathbf{D}$ was composed of a number of selected correspondence axes resulting from a correspondence analysis (CA) applied to the diet composition matrix based on taxonomic prey categories $\mathbf{W}_{t}$. Correspondence axes were selected according to the broken stick method. As for the PCA applied to EDFs, this analysis was chosen to decrease the number of dimensions used to describe fish diet variation and to remove collinearity between prey categories. Moreover, CA is a method adapted to the analysis of species abundance data without pre-transformation because abundance data within taxonomic prey categories are not normally distributed (Borcard et al. 2011). Model reduction was performed while considering variables of matrix I (and E ) separately and matrix $\mathbf{D}$ as a whole. Hence, matrix $\mathbf{I}$ (and $\mathbf{E}$ ) used in variation partitioning was (were) reduced, while matrix $\mathbf{D}$ was not when kept in the reduced model.

Prey categories involved in the relationship between diet and otolith shape (model 2, Fig. 3B)

In this analysis, matrix $\mathbf{D}$ was simply set equal to the diet composition matrix based on taxonomic prey categories $\mathbf{W}_{t}$ and model reduction was directly performed on Eq.3. Hence, matrices $\mathbf{I}$ (, E ) and $\mathbf{D}$ used in variation partitioning were all reduced. In order to identify the main prey categories involved in diet-otolith shape co-variation, permutation tests were performed for each selected prey category to test their significance. Moreover, to illustrate the 
relationship between the prey categories selected and otolith shape, 8 predicted otolith outlines were produced for each species in the following way.: A pRDA was performed on the otolith shape matrix $\mathbf{S}$ with the selected prey categories as explanatory variables and the selected individual-state (and environmental variables) as covariables. From this pRDA, 8 sets of coordinates in the matrix $\mathbf{S}$ space were predicted at the 8 combinations of \pm 1 standard deviation ( $s d)$ along the two first axes of the pRDA $\left\{\left(+s d_{1}, 0\right),\left(-s d_{1}, 0\right),\left(+s d_{1},+s d_{2}\right),\left(-s d_{1},+s d_{2}\right)\right.$, $\left.\left(+s d_{1},-s d_{2}\right),\left(-s d_{1},-s d_{2}\right),\left(0,+s d_{2}\right),\left(0,-s d_{2}\right)\right\}$ representing variation in linear combinations of the selected prey categories. Predictions in the matrix $\mathbf{S}$ space were then projected back to the matrix $\mathbf{F}$ space to produce predicted EFDs that were then used to draw predicted otolith shapes on the pRDA biplot.

\section{Contribution of diet relative composition vs food quantity to diet-otolith shape co-} variation (model 3, Fig. 3C)

In this analysis, matrix $\mathbf{D}$ was decomposed into a matrix representing the relative diet composition based on taxonomic prey categories $\mathbf{C}$ and a vector representing food quantity $\mathbf{Q}$ . The relative diet composition matrix $\mathbf{C}$ was obtained by performing a $\mathrm{CA}$ on the matrix of relative contribution of taxonomic prey categories to diet composition $\% W_{t, j}$ and selecting correspondence axes according to the broken stick method. The vector $\mathbf{Q}$ gathered the total weight of the stomach content of each individual, in other words the sums along rows $\sum_{j}{ }_{t, i j}$ of the diet composition matrix $\mathbf{W}_{t}$. In order to ensure that matrices $\mathbf{C}$ and $\mathbf{Q}$ were kept in the reduced model (with the ultimate aim to estimate their relative contribution to otolith shape variation), model reduction was based on a pRDA where the otolith shape matrix $\mathbf{S}$ was explained by matrix $\mathbf{I}$ (and $\mathbf{E}$ ) while matrices $\mathbf{C}$ and $\mathbf{Q}$ were considered as covariables. Hence, matrix $\mathbf{I}$ (and $\mathbf{E}$ ) used in variation partitioning were reduced, while matrices $\mathbf{C}$ and Q were not. 


\section{Relationship between diet energy composition and otolith shape (model 4, Fig. 3D)}

315 In this last analysis, matrix $\mathbf{D}$ was set equal to the diet composition matrix based on energetic

316

317

318 prey categories $\mathbf{W}_{e}$. Model reduction and variation partitioning were then performed as for model 1 .

All statistical analyses were performed using the package vegan (Oksanen et al. 2013) in the statistical environment R.3.1.1 ( $\mathrm{R}$ Core Team 2014). The R codes used in this study are available from the authors upon request.

\section{$\underline{\text { Results }}$}

Only results based on models without environmental confounding factors (Eq. 3a) are presented in details in this section. The rationale is that considering environmental variables at sampling site as related to otolith shape implies assuming that these environmental conditions are representative of those experienced by individuals during a substantial part of their life, which is subject to controversy for mobile organisms such as fish (see Discussion section). Only important differences between the results without and with environmental factors will be highlighted here. Detailed results when accounting for environmental factors (Eq.3b) can be found in Tables S2-S4-S5 and Figures S1-S2 in Supplementary material. In addition, the effects of individual-state variables on otolith shape have already been studied in detail (Hüssy 2008, Capoccioni et al. 2011). They were accounted for in the analyses to avoid potential confounding effects but were not the main focus of this study. Consequently, their effects are not detailed here but can be found in Tables S3-S4 in Supplementary material.

\section{Global relationship between diet and otolith shape (model 1)}


The reduced models explained between $11 \%$ and $26 \%$ of otolith shape variability for roundfish species. For flatfish species, percentages of explained variation were higher: $14 \%$ and $38 \%$ for plaice and sole, respectively (Table 2). Variation partitioning revealed that the individual matrix I explained the greatest part of variation in otolith shape for all species, between $19 \%$ and $27 \%$, except for red gurnard and European plaice for which it was not significant (Fig.4, first column). For all species, a significant diet contribution was detected at an alpha threshold of 5\%, except for tub gurnard and European plaice for which it was significant at an alpha threshold of $10 \%$ only. Matrix D explained between $10 \%$ and $16 \%$ of otolith shape variability (Fig.4). When including the environmental matrix $\mathbf{E}$ in the analysis, a significant diet contribution was detected at an alpha threshold of 5\% for European plaice that accounted for $13 \%$ of variation (Fig.S1, first column; Table S2).

\section{Prey categories involved in the relationship between diet and otolith shape (model 2)}

Between 2 to 7 taxonomic prey categories were selected in the reduced model according to species (Table 2) except for tub gurnard for which no taxonomic prey category was selected and hence no reduced model was tested. Explained variation by model 2 varied between $25 \%$ and 35\% according to species. As in model 1, the individual matrix I had a significant effect on otolith shape for all species (Fig.4, second column). It explained between 14\% and 23\% of shape variability. Concerning taxonomic prey categories, a significant contribution to otolith shape variation was detected for all species except one, tub gurnard (see above). The selected categories explained between $11 \%$ and $201 \%$ of otolith shape variability, which was slightly higher than the global effect of diet in model 1. According to species, the taxonomic prey categories contributing significantly differed in terms of relative frequency of occurrence $\% F_{j}$ and relative contribution of prey categories to $\operatorname{diet} \% W_{j}$. For striped red mullet, the significant taxonomic prey categories (Fig. 5) were either primary ones, i.e., characterized by a high $\% F_{t, j}$ 
and high $\% W_{t, j}$ such as annelida, or intermediary ones, i.e., characterized by a small $\% W_{j}$ with respect to $\% F_{j}$ such as caridea, or secondary ones, i.e., with a low $\% F_{j}$ and small $\% W_{j}$ such as bivalvia, brachyoura, and decapoda larvae (Fig.2). Similarly for red gurnard, influential taxonomic prey categories were either primary ones such as caridea or secondary ones such as gastropoda. For European plaice, only a primary taxonomic prey category was related to otolith shape, namely Echinodermata, contrary to common sole, for which only a secondary taxonomic prey category, cnidaria, was linked to otolith shape. When including the environmental matrix $\mathbf{E}$ in the analysis, the contribution of taxonomic prey categories to otolith shape variation increased to $40 \%$ for red gurnard but was relatively stable for the other species (Fig.S1, second column; Table S2).

Predicted otolith shapes as reconstructed in Fig. 5 revealed that diet was related to global otolith shape through the length/width ratio and thus otoliths' ellipticity, but also to finer details. Variations occurred in the otolith crenations, the width of the excisura major (the indentation between the rostrum and the antirostrum (Panfili et al. 2002), the length of the rostrum and the antirostrum, and the posterior part of the otolith shape.

\section{Contribution of relative diet composition vs food quantity to diet-otolith shape co- variation (model 3)}

For tub gurnard, model 3 was not estimated given the absence of diet effect in model 1 (and subsequently model 2). For the other species, model 3 explained between $9 \%$ and $37 \%$ of otolith shape variability (Table 2). Variation partitioning gave similar results in terms of individual effects to those obtained with model 1 except for European plaice for which the explained variation by the individual matrix $\mathbf{I}$ increased strongly (Fig.4, first and third columns, fourth line). Regarding diet, relative composition $\mathbf{C}$ contributed significantly to otolith shape variation for striped red mullet, red gurnard and common sole. Its effect explained $12 \%$ to $16 \%$ of 
variation. No significant contribution of $\mathbf{C}$ was found for European plaice even if variation partitioning attributed $8 \%$ of otolith shape variation to this matrix. In contrast, when the environmental matrix $\mathbf{E}$ was added in the model, a significant contribution of $\mathbf{C}$ was detected for European plaice while significance disappeared for common sole despite the slight decrease in percentage of variation explained (Fig.S1, third column; Table S2). Contrary to diet relative composition $\mathbf{C}$, food quantity $\mathbf{Q}$ did not contribute significantly to otolith shape variation whatever the species, including and excluding the environmental matrix $\mathbf{E}$ in the modele.

\section{Relationship between diet energy composition and otolith shape (model 4)}

The reduced models explained between $5 \%$ and $28 \%$ of otolith shape variation (Table 2 ). Variation partitioning revealed that the individual matrix I explained the greatest part of variation in otolith shape for all species, between 5\% and 27 (Fig.4, fourth column). A significant contribution of diet energetic composition was detected for tub gurnard and European plaice only and at an alpha threshold of $5 \%$ and $10 \%$, respectively. Matrix D explained $12 \%$ and $8 \%$ of otolith shape variation, respectively (Fig.4, fourth column).

\section{$\underline{\text { Discussion }}$}

In this study, we found that individual-state variables contributed the largest fraction of otolith shape variation in most cases. This result was expected given the already well described effect of individual-state variables on otolith shape and we will not discuss it here as there is ample literature on the subject (Cardinale et al. 2004, Hüssy 2008, Capoccioni et al. 2011). Besides this known effect, we showed an intra-population relationship between diet and otolith shape for all fish species studied, although the relationship was less robust for tub gurnard. For the latter, only the relationship between diet energetic composition and otolith shape was significant at an alpha threshold of 5\%, the global relationship between diet weight composition 
and otolith shape being significant at an alpha threshold of $10 \%$ only. Small sample size of this species compared to the others may explain a lower power of signal detection. Then we were able to relate either primary, intermediary or secondary prey categories to otolith shape variations. Moreover, otolith reconstructions suggest that these variations could affect both global shape and its finer details. Then, by comparing the contributions of food composition and quantity, we showed that food composition contributed more largely to otolith shape variation than the quantity of food ingested by fish. Finally, for only two species, a diet influence based on energetic content categories was detected significant.

\section{The role of organic matrix composition in otolith biomineralization}

Although the organic matrix of sagittal otoliths represents a minor fraction of the total material (Carlström 1963, Degens et al. 1969), it plays an important role in otolith formation. It actually controls the nucleation, the crystallization, the orientation and the morphology as well as the polymorphism of crystal units the otolith is composed of (Nagasawa 2013). The organic matrix is mainly composed of proteins, amino acids (AAs), collagens and proteoglycans, which precursors are secreted by the saccular epithelium in the endolymph (Payan et al. 2004). However, only 3 major proteins are present in their definite form both in the endolymph and the otolith. This suggests that the organic matrix is not directly composed of compounds present in endolymph but also of proteins derived from the modification of precursors during their deposition onto the otolith (Borelli et al. 2001). McMahon et al. (2010) observed that AAs' $\delta^{13} \mathrm{C}$ values in fish muscle and in their diet co-varied, with significant differences diet treatments. Moreover, they showed that AAs' $\delta^{13} \mathrm{C}$ values in muscles and in otoliths were correlated with a slope around 1 and thus recorded an identical dietary information (McMahon et al. 2011). Consequently, the AAs found in otolith proteins come from the food consumed by fish. 
Otolith shape is determined by its crystalline architecture (calcium carbonate $\mathrm{CaCO}_{3}$ ). Several proteins are known to control the $\mathrm{CaCO}_{3}$ polymorphism (aragonite, calcite or vaterite) and the morphology of its crystal units. Starmaker (Söllner et al. 2003) and Otolith Matrix Macromolecule-64 (OMM-64) (Tohse et al. 2009) are water-soluble and acidic (due to a calcium-binding region rich in glutamate) glycoproteins involved in the control of crystal polymorphism (Nagasawa 2013). The Otolith Matrix Protein-1 (OMP-1) is another watersoluble protein required for normal otolith growth and for the deposition of another otolith protein, otolin-1. The latter is a collagenous protein that makes up the structural network for subsequent calcification, and thus stabilizes the otolith's mineral and organic fractions and insures the correct arrangement of otoliths on the sensory epithelium (Murayama et al. 2005).

\section{Potential mechanisms underlying the relationship between diet composition and otolith}

\section{shape}

In the present study, a significant relationship between diet taxonomic composition and otolith shape was detected for all species except for one. According to the taxonomic prey categories consumed, otolith shape presented some variations in both global shape, such as the degree of ellipticity, and finer details, such as otolith crenation or the width of the excisura major. Two hypotheses, or a combination of both, could explain the correlation between otolith shape and diet taxonomic composition. First, the total quantity of proteins in the saccular endolymph could vary according to the quantity of proteins in the prey consumed, which would affect the rate of organic matrix synthesis and thus $\mathrm{CaCO}_{3}$ deposition and ultimately otolith growth. Protein consumption has been known to have the highest regulatory impact on protein synthesis (Houlihan et al. 1988). Consequently, diet taxonomic composition could influence "global" otolith shape through effects on otolith growth. Secondly, the proteic composition of the organic matrix, i.e. the relative quantity of water-soluble, water-insoluble and insoluble proteins, may 
change according to food composition, which would impact the crystal structure (orientation, morphology, and polymorphism) of precipitated $\mathrm{CaCO}_{3}$ and, thus, otolith shape. More precisely, food composition varies in terms of proteins or even AAs, whether essential (e.g. leucine) or not (e.g. glutamic acid), that are necessary for the synthesis of some otolith matrix proteins involved in the control of crystal structure (Asano \& Mugiya 1993, Davis et al. 1995, Sasagawa \& Mugiya 1996, Nagasawa 2013). Consequently, food proteic composition could have a direct contribution to variations in otolith crenation or/and an indirect contribution through its effect on otolith growth, which impacts global otolith shape. In addition, some proteoglycan and polysaccharide are present in both the saccular endolymph and the organic matrix (Murayama et al. 2005). Even if their role in otolith biomineralization is unknown, variability in their quantity and composition in prey could also impact otolith shape in the same way as proteins.

Diet energetic composition was significantly related to otolith shape in two species only. Contrary to proteins and glucids, lipids are not components of the otolith organic matrix, which could explain the absence of a strong relationship between the diet energetic composition and otolith shape. Lipids are indeed the main determinant of prey energetic content as energy per unit of mass in prey is positively correlated to their lipid content and generally negatively correlated to their protein content (Spitz et al. 2010). The fact that diet taxonomic composition was better correlated with otolith shape variation than diet energetic composition suggests that prey lipid versus protein content is less related to otolith shape variation than prey composition (in opposition to amount) in terms of proteins and carbonates. This result seems rather logical given the composition of the otolith and its precursors when thinking about a direct effect on otolith shape through its organic matrix. In contrast, it may seem surprising when envisaging an indirect effect on otolith shape through otolith growth. High dietary lipid levels can improve body size growth (Vergara et al. 1999, Boujard et al. 2004). Diet lipid content is thus likely to 
be related to otolith growth and thus shape. The lack of strong relationship could result from several aspects. First, high dietary protein levels also favour faster growth. Given that lipid and protein levels in diet are oppositely correlated to diet energy content (Spitz et al. 2010), the two effects could cancel each other out when considering the effect of diet energetic composition. Second, some of the reduced models included a size effect that could absorb the indirect effect of diet energetic composition through growth. Third, diet energetic composition was based on 3 qualitative, relatively coarse, energetic prey categories, which may not be precise enough to detect a relationship. Studies based on a proper quantification of diet energy content, through bomb calorimetry of stomach contents for instance, or on the lipid composition of prey would allow to investigate further the potential relationship between diet energy content and otolith shape.

In this study, locations of variation in otolith shape related to food composition were identified from reconstructed shapes. Although these reconstructions were "caricatures" predicted from a statistical model limited to individuals from the eastern English Channel and to our observations in terms of individual-state, they highlighted the large number of otolith shape areas co-varying with food composition suggesting the importance of understanding otolith biomineralization 3D processes. Otolith shape variation could be also explained by variations of spatial distribution of precursors due to some physical constraints on the saccule which would impact the otolith shape. However, the current lack of knowledge regarding such processes prevents from clearly evaluating the likelihood of this hypothesis.

\section{Absence of relationship between food quantity and otolith shape}

No significant relationship between food quantity and otolith shape was detected in this study. This result contrasts with several works that showed experimentally that food quantity impacted otolith shape both indirectly via variation in otolith growth creating variation in "global" otolith 
shape and directly on otolith crenations (Gagliano \& McCormick 2004, Cardinale et al. 2004, Hüssy 2008). We could raise the assumption that in the present study, the quantity of ingested food did not differ sufficiently between individuals in order to observe a significant influence on otolith shape. Likewise, Hüssy (2004) did not observed any effect of food quantity on otolith opacity and on the ratio between water-soluble and water- insoluble proteins in the organic matrix whereas, under more severe food restriction for a longer period, Høie et al (2008) observed that more translucent otolith material was deposited. Such apparent discrepancies are well reconciled under the light of temperature and food effect interactions (either synergetic or antagonistic) on otolith opacity (Fablet et al. 2011). Moreover, here food quantity was measured as the sum of the weights of all prey items found in an individual's stomach. However, prey items in stomach contents are digested at varying degrees according to individuals, which can introduce a bias in the estimation of inter-individual differences in ingested food quantity (Gannon 1976).

\section{Limitations of the study}

The imprecision of food quantity measure highlights a potential, more general, limitation of stomach content analysis that only provides a snapshot of fishes' diet, and in this precise case at a single season as all fish in this study have been sampled in October. The interpretation of the results in the present study rely on the assumption that observed inter-individual differences in diet are consistent other a sufficiently long time period to be related to inter-individual otolith shape differences. It should be noted here that the assumption is concerned with the representativity of inter-individual differences, i.e. individuals' specialization, and not of individuals' diet itself. In other words, the assumption is that diet difference at a given time gives an index of dietary specialization even though individuals' diet may vary through time. To our knowledge, such an assumption has never been directly confirmed nor invalidated in 
fish given that no longitudinal study on fish diet, i.e. with repeated observations of prey selectivity or stomach content on the same individuals, was performed for testing. Although the possibility that this hypothesis does not hold cannot be totally ruled out, several arguments can be brought in its support. There is ample literature on the importance and prevalence of individual diet specialization (see reviews in Bolnick et al. 2003; Araújo et al. 2011), notably long-term trophic specialization in freshwater and marine vertebrates (e.g. Bearhop et al. 2006, Newsome et al. 2009, Hückstädt et al. 2011, Rosenblatt et al. 2015) including fish (e.g. Beaudoin et al. 1999, Svanbäck \& Persson 2004, Matich et al. 2011), that support this assumption based on isotopic data. Consistent inter-individual differences in several behavioural traits that may affect diet have also been documented in fish (see review in Mittelbach et al. 2014) such as habitat use and movements (e.g. Matich \& Heithaus 2015) or boldness (e.g. Ward et al. 2004, Harcourt et al. 2009). A more technical argument is that the presence of multiple prey items per stomach ensures that cross-sectional samples of individuals' diet are relevant to estimate individual diet specialization (Araújo et al. 2011). An additional argument in support of our assumption comes from the relative stability of our results across the three different analyses based on taxonomic prey categories for each species and the relative low standard deviations of fractions in variation partitioning obtained from bootstrapping analyses (Table 3, Table.S5). It should also be noted that, despite its limitations, stomach content analysis is the only way to obtain an indication of ingested food quantity in natural condition. In contrast, carbon stable isotope ratios could provide a temporally-integrated view of individuals' diet composition and account for seasonal changes in diet, but without allowing the quantification of the amount of food ingested. Additionally, the precise identification of the consumed prey items from carbon stable isotope ratios by using so-called mixing models requires knowledge of the isotopic ratios of all potential preys and of the isotopic fractionation between preys and consumers (Post 2002, Fry 2007). Still, variation of carbon stable isotope 
ratio (in muscles and/or otolith) across individuals could be used to describe variability in individual diet composition with the aim of linking it to the otolith shape variability. This would complement the results obtained in this study.

Likewise, the environmental variables considered in our supplementary analyses (see Supplementary material Fig.S1-S2 and Tables S2-S4), i.e. temperature, depth, salinity, longitude and latitude, were a snapshot of the environment experienced by individuals as they were measured at sampling site and averaged over a single month. Similarly to stomach contents, their use in the analyses (Eq. $2 b$ and $3 b$ ) relies on the assumption that they are representative of inter-individual differences in the environment experienced over a sufficiently long-time period to be related to otolith shape. Such an assumption may seem unlikely for a majority of fish given their mobility, which could explain the fact that for a majority of the studied species, the environmental matrix was not significantly related to otolith shape (Fig.S1). However, for European plaice, the inclusion of the environmental matrix in the analysis has allowed describing a supplementary part of otolith shape variation that, it seems, was obscuring the diet signal since the diet matrix also became significant. This result may be linked to the supposedly lower mobility of benthic flatfish such as plaice. In order to have a temporallyintegrated view of the environment experienced by individuals possibly accounting also for seasonality, otolith chemistry such as the variation of oxygen isotopic ratios as an index for temperature (Kalish 1991) or the ratio $\mathrm{Sr} / \mathrm{Ca}$ as an index for the salinity (Secor 1992) could be used in future studies. Moreover, all fish in this study have been sampled in October, i.e. in a single season. It would be interesting to consider the implication of seasonality on the relationship between diet and environment on the one hand and otolith shape on the other.

In summary, an intra-population relationship between diet and otolith shape was detected for several roundfish and flatfish species from the eastern English Channel. Detailed analyses 
revealed that both main and secondary prey categories were involved in this relationship and that variations influenced both the otolith's global shape and some finer details. The contribution of relative diet taxonomic composition to otolith shape variation was much higher than that of ingested food quantity represented by the weight of prey items. Finally, diet energetic composition was correlated with otolih shape of only one species and marginally for another. Gagliano and McCormick (2004) had suggested that otolith shape could be used to discriminate fine scale events, such as the magnitude and periodicity of feeding in wild fish populations, in addition to the discrimination of stocks and populations based on coarser aspects such as life-history differences. The present study shows that diet composition may also be a source of otolith shape variability within populations through direct and/or indirect (via otolith growth) processes. This introduces a novel potential interpretation of three classically known effects on otolith shape. First, otolith shape variation across age and size is generally assigned to ontogenetic changes in metabolism and physiology (Campana \& Casselman 1993, Mérigot et al. 2007). Ontogenetic changes in diet composition could also contribute directly to otolith shape variation, thereby acting as a confounding factor (Morat et al. 2012, Vignon 2012). Likewise, sexual dimorphism in otolith shape is generally attributed to physiological differences between sexes. However, sexual dimorphism in diet composition, especially at the time of mating, has been documented in several fish species (Casselman \& Schulte-Hostedde 2004, Tsuboi et al. 2011) and could thus also explain otolith shape dimorphism. Finally, environmental abiotic factors, such as temperature and salinity, are also known to influence otolith shape variation (Lombarte \& Lleonart 1993) and spatial variation in otolith shape are often interpreted as resulting from habitat differentiation (Morat et al. 2012). However, such variation in abiotic factors is generally related to differences in prey categories available to individual predator, such that geographical variations in diet composition could also generate geographical variation in otolith shape (Vignon 2012). Such applied consequences call for 
613

further investigations of the sources of otolith shape variation and their mechanistic effect on biomineralization, notably those related to diet.

\section{$\underline{\text { References }}$}

Allemand D, Mayer-Gostan N, De Pontual H, Boeuf G, Payan P (2007) Fish Otolith Calcification in Relation to Endolymph Chemistry. In: Bäuerlein E (ed) Handbook of Biomineralization. WileyVCH Verlag GmbH, p 291-308

Amara R, Meziane T, Gilliers C, Hermel G, Laffargue P (2007) Growth and condition indices in juvenile sole Solea solea measured to assess the quality of essential fish habitat. Mar Ecol Prog Ser 351:201-208

Anthony JA, Roby DD, Turco KR (2000) Lipid content and energy density of forage fishes from the northern Gulf of Alaska. J Exp Mar Biol Ecol 248:53-78

Araújo MS, Bolnick DI, Layman CA (2011) The ecological causes of individual specialisation. Ecol Lett 14:948-958

Asano M, Mugiya Y (1993) Biochemical and calcium-binding properties of water-soluble proteins isolated from otoliths of the tilapia, Orecchromis niloticus. Comp Biochem Physiol Part B Comp Biochem 104:201-205

Bearhop S, Phillips RA, McGill R, Cherel Y, Dawson DA, Croxall JP (2006) Stable isotopes indicate sexspecific and long-term individual foraging specialisation in diving seabirds. Mar Ecol Prog Ser 311:157-164

Beaudoin CP, Tonn WM, Prepas EE, Wassenaar LI (1999) Individual specialization and trophic adaptability of northern pike (Esox lucius): an isotope and dietary analysis. Oecologia 120:386-396

Bolles KL, Begg GA (2000) Distinction between silver hake (Merluccius bilinearis) stocks in US waters of the northwest Atlantic based on whole otolith morphometrics. Fish Bull 98:451-462

Bolnick DI, Svanbäck R, Fordyce JA, Yang LH, Davis JM, Hulsey CD, Forister ML (2003) The Ecology of Individuals: Incidence and Implications of Individual Specialization. Am Nat 161:1-28

Borcard D, Gillet F, Legendre P (2011) Numerical Ecology with R. Springer

Borelli G, Mayer-Gostan N, Pontual H de, Boeuf G, Payan P (2001) Biochemical Relationships Between Endolymph and Otolith Matrix in the Trout (Oncorhynchus mykiss) and Turbot (Psetta maxima). Calcif Tissue Int 69:356-364

Boujard T, Gélineau A, Covès D, Corraze G, Dutto G, Gasset E, Kaushik S (2004) Regulation of feed intake, growth, nutrient and energy utilisation in European sea bass (Dicentrarchus labrax) fed high fat diets. Aquaculture 231:529-545

Buckel JA, Sharack BL, Zdanowicz VS (2004) Effect of diet on otolith composition in Pomatomus saltatrix, an estuarine piscivore. J Fish Biol 64:1469-1484 
Caldow C, Wellington GM (2003) Patterns of annual increment formation in otoliths of pomacentrids in the tropical western Atlantic: implications for population age-structure examination. Mar Ecol Prog Ser 265:185-195

Campana SE, Casselman JM (1993) Stock Discrimination Using Otolith Shape Analysis. Can J Fish Aquat Sci 50:1062-1083

Capoccioni F, Costa C, Aguzzi J, Menesatti P, Lombarte A, Ciccotti E (2011) Ontogenetic and environmental effects on otolith shape variability in three Mediterranean European eel (Anguilla anguilla, L.) local stocks. J Exp Mar Biol Ecol 397:1-7

Cardinale M, Doering-Arjes P, Kastowsky M, Mosegaard H (2004) Effects of sex, stock, and environment on the shape of known-age Atlantic cod (Gadus morhua) otoliths. Can J Fish Aquat Sci 61:158-167

Carlström D (1963) A Crystallographic Study of Vertebrate Otoliths. Biol Bull 125:441-463

Casselman SJ, Schulte-Hostedde Al (2004) Reproductive roles predict sexual dimorphism in internal and external morphology of lake whitefish, Coregonus clupeaformis. Ecol Freshw Fish $13: 217-222$

Castonguay M, Simard P, Gagnon P (1991) Usefulness of Fourier Analysis of Otolith Shape for Atlantic Mackerel (Scomber scombrus) Stock Discrimination. Can J Fish Aquat Sci 48:296-302

Coppin F, Carpentier A, Delpech J-P, Schlaich I (2002) Manuel des protocoles de campagne halieutique. Campagnes CGFS. V 3.

Dauvin J-C, Joncourt M (1989) Energy Values of Marine Benthic Invertebrates from the Western English Channel. J Mar Biol Assoc U K 69:589-595

Davis JG, Oberholtzer JC, Burns FR, Greene MI (1995) Molecular cloning and characterization of an inner ear-specific structural protein. Science 267:1031-1034

Degens ET, Deuser WG, Haedrich RL (1969) Molecular structure and composition of fish otoliths. Mar Biol 2:105-113

Elsdon TS, Ayvazian S, McMahon KW, Thorrold SR (2010) Experimental evaluation of stable isotope fractionation in fish muscle and otoliths. Mar Ecol Prog Ser 408:195-205

Fablet R, Pecquerie L, Pontual H de, Høie H, Millner R, Mosegaard H, Kooijman SALM (2011) Shedding Light on Fish Otolith Biomineralization Using a Bioenergetic Approach. PLoS ONE 6:e27055

Fernandez-Jover D, Sanchez-Jerez P (2015) Comparison of diet and otolith growth of juvenile wild fish communities at fish farms and natural habitats. ICES J Mar Sci J Cons 72:916-929

Fraser AJ (1989) Triacylglycerol Content as a Condition Index for Fish, Bivalve, and Crustacean Larvae. Can J Fish Aquat Sci 46:1868-1873

Fry B (2007) Stable Isotope Ecology. Springer Science \& Business Media

Gagliano M, McCormick M (2004) Feeding history influences otolith shape in tropical fish. Mar Ecol Prog Ser 278:291-296 
Gannon JE (1976) The Effects of Differential Digestion Rates of Zooplankton by Alewife, Alosa pseudoharengus, on Determinations of Selective Feeding. Trans Am Fish Soc 105:89-95

Godfriaux BL (1969) Food of predatory demersal fish in Hauraki Gulf. N Z J Mar Freshw Res 3:518-544

Guibbolini M, Borelli G, Mayer-Gostan N, Priouzeau F, De Pontual H, Allemand D, Payan P (2006) Characterization and variations of organic parameters in teleost fish endolymph during daynight cycle, starvation and stress conditions. Comp Biochem Physiol A Mol Integr Physiol 145:99-107

Harcourt JL, Ang TZ, Sweetman G, Johnstone RA, Manica A (2009) Social Feedback and the Emergence of Leaders and Followers. Curr Biol 19:248-252

Høie H, Folkvord A, Mosegaard H, Li L, Clausen LAW, Norberg B, Geffen AJ (2008) Restricted fish feeding reduces cod otolith opacity. J Appl Ichthyol 24:138-143

Houlihan DF, Hall SJ, Gray C, Noble BS (1988) Growth Rates and Protein Turnover in Atlantic Cod, Gadus morhua. Can J Fish Aquat Sci 45:951-964

Hückstädt LA, Koch PL, McDonald BI, Goebel ME, Crocker DE, Costa DP (2011) Stable isotope analyses reveal individual variability in the trophic ecology of a top marine predator, the southern elephant seal. Oecologia 169:395-406

Hüssy K (2008) Otolith shape in juvenile cod (Gadus morhua): Ontogenetic and environmental effects. J Exp Mar Biol Ecol 364:35-41

Hüssy K, Mosegaard H (2004) Atlantic cod (Gadus morhua) growth and otolith accretion characteristics modelled in a bioenergetics context. Can J Fish Aquat Sci 61:1021-1031

Hüssy K, Mosegaard H, Jessen F (2004) Effect of age and temperature on amino acid composition and the content of different protein types of juvenile Atlantic cod (Gadus morhua) otoliths. Can J Fish Aquat Sci 61:1012-1020

Huuskonen H, Karjalainen J (1998) A preliminary study on the relationships between otolith increment width, metabolic rate and growth in juvenile whitefish (Coregonus lavaretus L.). Arch Für Hydrobiol 142:371-383

ICES (2010) Report of the Workshop on Age Reading of North Sea (IV) and Skagerrak-Katt egat (IIla) Plaice (WKARP), 2- 5 November 2010 , ljmuiden, The Netherlands . ICES CM 2010/ACOM: 45. $65 \mathrm{pp}$.

ICES (2012) Report of the workshop on age reading of red mullet and striped red mullet, 2-6 July 2012, Boulogne-sur-Mer, France. ICES CM2012/ACOM:60.52pp.

ICES (2014) Report of the Workshop for maturity staging chairs (WKMATCH), 11-15 June 2012, Split, Croatia. ICES CM 2012/ACOM:58. 57 pp.

Jolivet A, Bardeau J-F, Fablet R, Paulet Y-M, Pontual H de (2013) How do the organic and mineral fractions drive the opacity of fish otoliths? Insights using Raman microspectrometry. Can J Fish Aquat Sci 70:711-719

Kalish JM (1991) Oxygen and carbon stable isotopes in the otoliths of wild and laboratory-reared Australian salmon (Arripis trutta). Mar Biol 110:37-47 
Kuhl FP, Giardina CR (1982) Elliptic Fourier features of a closed contour. Comput Graph Image Process 18:236-258

L'Abée-Lund JH (1988) Otolith shape discriminates between juvenile Atlantic salmon, Salmo salar L., and brown trout, Salmo trutta L. J Fish Biol 33:899-903

Lazure P, Dumas F (2008) An external-internal mode coupling for a 3D hydrodynamical model for applications at regional scale (MARS). Adv Water Resour 31:233-250

Lestrel PE (2008) Fourier Descriptors and Their Applications in Biology. Cambridge University Press

Lombarte A, Lleonart J (1993) Otolith size changes related with body growth, habitat depth and temperature. Environ Biol Fishes 37:297-306

Mahé K, Moerman M, Holmes I, Boiron A, Elleboode R (2012) Report of the Sole ( Solea solea ) in the Bay of Biscay Otolith Exchange Scheme 2011. :14 pp

Massou AM, Panfili J, Laë R, Baroiller JF, Mikolasek O, Fontenelle G, Le Bail P-Y (2002) Effects of different food restrictions on somatic and otolith growth in Nile tilapia reared under controlled conditions. J Fish Biol 60:1093-1104

Matich P, Heithaus MR (2015) Individual variation in ontogenetic niche shifts in habitat use and movement patterns of a large estuarine predator (Carcharhinus leucas). Oecologia 178:347359

Matich P, Heithaus MR, Layman CA (2011) Contrasting patterns of individual specialization and trophic coupling in two marine apex predators. J Anim Ecol 80:294-305

McMahon KW, Fogel ML, Elsdon TS, Thorrold SR (2010) Carbon isotope fractionation of amino acids in fish muscle reflects biosynthesis and isotopic routing from dietary protein. J Anim Ecol 79:1132-1141

Mérigot B, Letourneur Y, Lecomte-Finiger R (2007) Characterization of local populations of the common sole Solea solea (Pisces, Soleidae) in the NW Mediterranean through otolith morphometrics and shape analysis. Mar Biol 151:997-1008

Mittelbach GG, Ballew NG, Kjelvik MK (2014) Fish behavioral types and their ecological consequences. Can J Fish Aquat Sci 71:927-944

Molony BW, Choat JH (1990) Otolith increment widths and somatic growth rate: the presence of a time-lag. J Fish Biol 37:541-551

Molony BW, Sheaves MJ (1998) Otolith increment widths and lipid contents during starvation and recovery feeding in adult Ambassis vachelli (Richardson). J Exp Mar Biol Ecol 221:257-276

Morat F, Letourneur Y, Nérini D, Banaru D, Batjakas LE (2012) Discrimination of red mullet populations (Teleostean, Mullidae) along multi-spatial and ontogenetic scales within the Mediterranean basin on the basis of otolith shape analysis. Aquat Living Resour 25:27-39

Mosegaard H, Svedäng H, Taberman K (1988) Uncoupling of Somatic and Otolith Growth Rates in Arctic Char (Salvelinus alpinus) as an Effect of Differences in Temperature Response. Can J Fish Aquat Sci 45:1514-1524 
Murayama E, Herbomel P, Kawakami A, Takeda H, Nagasawa H (2005) Otolith matrix proteins OMP-1 and Otolin-1 are necessary for normal otolith growth and their correct anchoring onto the sensory maculae. Mech Dev 122:791-803

Nagasawa H (2013) The Molecular Mechanism of Calcification in Aquatic Organisms. Biosci Biotechnol Biochem 77:1991-1996

Newsome SD, Tinker MT, Monson DH, Oftedal OT, Ralls K, Staedler MM, Fogel ML, Estes JA (2009) Using stable isotopes to investigate individual diet specialization in California sea otters (Enhydra lutris nereis). Ecology 90:961-974

Norrbin F, Båmstedt U (1984) Energy contents in benthic and planktonic invertebrates of Kosterfjorden, Sweden. A comparison of energetic strategies in marine organism groups. Ophelia 23:47-64

Oksanen J, Blanchet FG, Kindt R, Legendre P, Minchin PR, O'Hara RB, Simpson GL, Peter S, Stevens MHH, Wagner H (2013) vegan: Community Ecology Package. R package version 2.0-10.

Panfili J, De Pontual H, Troadec H, Wright PJ (2002) Manual of fish sclerochronology, Coédition Ifremer-IRD.

Payan P, Borelli G, Boeuf G, Mayer-Gostan N (1998) Relationship between otolith and somatic growth:consequence of starvation on acid-base balance inplasma and endolymph in the rainbow trout Oncorhynchus mykiss. Fish Physiol Biochem 19:35-41

Payan P, Edeyer A, Pontual H de, Borelli G, Boeuf G, Mayer-Gostan N (1999) Chemical composition of saccular endolymph and otolith in fish inner ear: lack of spatial uniformity. Am J Physiol Regul Integr Comp Physiol 277:123-131

Payan P, Pontual H de, Bœuf G, Mayer-Gostan N (2004) Endolymph chemistry and otolith growth in fish. Comptes Rendus Palevol 3:535-547

Pisam M, Payan P, LeMoal C, Edeyer A, Boeuf G, Mayer-Gostan N (1998) Ultrastructural study of the saccular epithelium of the inner ear of two teleosts, Oncorhynchus mykiss and Psetta maxima. Cell Tissue Res 294:261-270

Post DM (2002) Using stable isotopes to estimate trophic position: models, methods, and assumptions. Ecology 83:703-718

R Core Team (2014) R: A language and environment for statistical computing. R Foundation for Statistical Computing, Vienna, Austria. URL http://www.R-project.org/.

Rohlf FJ, Archie JW (1984) A Comparison of Fourier Methods for the Description of Wing Shape in Mosquitoes (Diptera: Culicidae). Syst Biol 33:302-317

Rosenblatt AE, Nifong JC, Heithaus MR, Mazzotti FJ, Cherkiss MS, Jeffery BM, Elsey RM, Decker RA, Silliman BR, Jr LG, Lowers RH, Larson JC (2015) Factors affecting individual foraging specialization and temporal diet stability across the range of a large "generalist" apex predator. Oecologia 178:5-16

Sanchez-Jerez P, Gillanders BM, Kingsford MJ (2002) Spatial variability of trace elements in fish otoliths: comparison with dietary items and habitat constituents in seagrass meadows. J Fish Biol 61:801-821 
Sasagawa T, Mugiya Y (1996) Biochemical Properties of Water-Soluble Otolith Proteins and the Immunobiochemical Detection of the Proteins in Serum and Various Tissues in the Tilapia Oreochromis niloticus. Fish Sci 62:970-976

Secor D (1992) Application of Otolith Microchemistry Analysis to Investigate Anadromy. Fish Bull 90:798-806

Söllner C, Burghammer M, Busch-Nentwich E, Berger J, Schwarz H, Riekel C, Nicolson T (2003) Control of Crystal Size and Lattice Formation by Starmaker in Otolith Biomineralization. Science 302:282-286

Spitz J, Mourocq E, Schoen V, Ridoux V (2010) Proximate composition and energy content of forage species from the Bay of Biscay: high- or low-quality food? ICES J Mar Sci J Cons 67:909-915

Steimle FW, Terranova RJ (1985) Energy equivalents of marine organisms from the continental shelf of the temperate northwest Atlantic. J Northw Atl Fish Sci 6:117-124

Stransky C, Murta AG, Schlickeisen J, Zimmermann C (2008) Otolith shape analysis as a tool for stock separation of horse mackerel (Trachurus trachurus) in the Northeast Atlantic and Mediterranean. Fish Res 89:159-166

Suthers IM, Fraser A, Frank KT (1992) Comparison of lipid, otolith and morphometric condition indices of pelagic juvenile cod Gadus morhua from the Canadian Atlantic. Mar Ecol Prog Ser 84:31-40

Svanbäck R, Persson L (2004) Individual diet specialization, niche width and population dynamics: implications for trophic polymorphisms. J Anim Ecol 73:973-982

Thorrold SR, Jones CM, Campana SE (1997) Response of Otolith Microchemistry to Environmental Variations Experienced by Larval and Juvenile Atlantic Croaker (Micropogonias undulatus). Limnol Oceanogr 42:102-111

Tohse H, Saruwatari K, Kogure T, Nagasawa H, Takagi Y (2009) Control of Polymorphism and Morphology of Calcium Carbonate Crystals by a Matrix Protein Aggregate in Fish Otoliths. Cryst Growth Des 9:4897-4901

Tsuboi M, Gonzalez-Voyer A, Höglund J, Kolm N (2011) Ecology and mating competition influence sexual dimorphism in Tanganyikan cichlids. Evol Ecol 26:171-185

Tuset VM, Rosin PL, Lombarte A (2006) Sagittal otolith shape used in the identification of fishes of the genus Serranus. Fish Res 81:316-325

Vergara JM, López-Calero G, Robaina L, Caballero MJ, Montero D, Izquierdo MS, Aksnes A (1999) Growth, feed utilization and body lipid content of gilthead seabream (Sparus aurata) fed increasing lipid levels and fish meals of different quality. Aquaculture 179:35-44

Vignon M (2012) Ontogenetic trajectories of otolith shape during shift in habitat use: Interaction between otolith growth and environment. J Exp Mar Biol Ecol 420-421:26-32

Vignon M, Morat F (2010) Environmental and genetic determinant of otolith shape revealed by a non-indigenous tropical fish. Mar Ecol Prog Ser 411:231-241 
Walther B, Thorrold S (2006) Water, not food, contributes the majority of strontium and barium deposited in the otoliths of a marine fish. Mar Ecol Prog Ser 311:125-130

Ward AJW, Thomas P, Hart PJB, Krause J (2004) Correlates of boldness in three-spined sticklebacks (Gasterosteus aculeatus). Behav Ecol Sociobiol 55:561-568

Worthington DG, Fowler AJ, Doherty PJ (1995) Determining the most efficient method of age determination for estimating the age structure of a fish population. Can J Fish Aquat Sci 52:2320-2326 
Fig. 1: Map of sampling areas in the eastern English Channel according to species. Each circle represents a fishing site and circle size gives the relative sampling abundance.

Fig. 2: Contribution of taxonomic prey categories to species specific diet, measured in terms of relative weight $\left(\% \mathrm{~W}_{\mathrm{t}}\right.$, black triangle $)$ and relative frequency of occurrence $\left(\% \mathrm{~F}_{\mathrm{t}}\right.$, grey open circle).

Fig. 3: Schematic representation of the sequential steps of the four RDA statistical analyses performed to investigate the four questions of the study: (A) the global relationship between diet and otolith shape (model 1), (B) the prey categories involved in this relationship (model 2), (C) the relative contributions of diet relative composition and quantity to diet-otolith shape co-variation (model 3) and (D) the relationship between diet energy composition and otolith shape (model 4).

Fig. 4: Variation partitioning between diet and individual-state for the four questions investigated for each species. Questions investigated are organized into columns whereas species are organized into lines. Each circle corresponds to one matrix: diet matrix $\mathbf{D}$,: individual-state variable matrix $\mathbf{I}$, diet relative composition matrix $\mathbf{C}$, and food quantity $\mathbf{Q}$. The number in the non-overlapping part of each circle represents the unique contribution in percentage of variation of the corresponding matrix. The number in the overlapping parts of the circles represent the joint contribution in percentage of variation of the corresponding matrices. Standard deviations obtained by bootstrapping are given for unique contributions only for ease of reading. All contributions and their standard deviations are given in Table 3 for more details. P-values of contribution fractions are indicated by the following symbols: $<10 \% \dagger,<5 \% *,<1 \% * *,<0.1 \% * * *$.

Fig. 5: pRDA biplot of otolith shape constrained by selected taxonomic prey categories and conditioned by selected individual variables (model 3) according to species. Explanatory variables with a significant effect (permutation test) on otolith shape are in red, the corresponding $\mathrm{P}$-value being indicated by the following symbols: $<5 \% *,<1 \% * *,<0.1 \% * * *$. Each circle represents an individual and its size represents the individual total length. For each species, eight otolith shapes have been reconstructed from model predictions illustrating the relationship between diet and otolith shape.

Fig. S1: Variation partitioning between diet and individual-state for the four questions investigated for each species. Questions investigated are organized into columns whereas species are organized into lines. Each circle corresponds to one matrix: diet matrix D, environmental matrix $\mathbf{E}$, individual-state variable matrix $\mathbf{I}$, diet relative composition matrix $\mathbf{C}$, and food quantity $\mathbf{Q}$. The number in the non-overlapping part of each circle represents the unique contribution in percentage of variation of the corresponding matrix. The number in the overlapping parts of the circles represent the joint contribution in percentage of variation of the corresponding matrices. Standard deviations obtained by bootstrapping are given for unique contributions only for ease of reading. All contributions and their standard deviations are given in Table S5 for more details. P-values of contribution fractions are indicated by the following symbols: $<10 \% \dagger,<5 \% *,<1 \% * *,<0.1 \% * * *$. 
Fig. S2: pRDA biplot of otolith shape constrained by selected taxonomic prey categories and conditioned by selected individual variables and environmental variables (model 3) according to species. Explanatory variables with a significant effect (permutation test) on otolith shape are in red, the corresponding P-value being indicated by the following symbols: $<5 \% *$, $<1 \% * *,<0.1 \% * * *$. Each circle represents an individual and its size represents the individual total length. For each species, eight otolith shapes have been reconstructed from model predictions illustrating the relationship between diet and otolith shape.

Fig. S3: Contribution of enegetic prey categories (o high, o medium, o low) to species specific diet, measured in terms of relative weight $\left(\% \mathrm{~W}_{\mathrm{e}}\right)$. 
Relative weight $(\mathrm{Wt})$ and relative frequency $(\mathrm{Ft})$ of occurrence $(\%)$

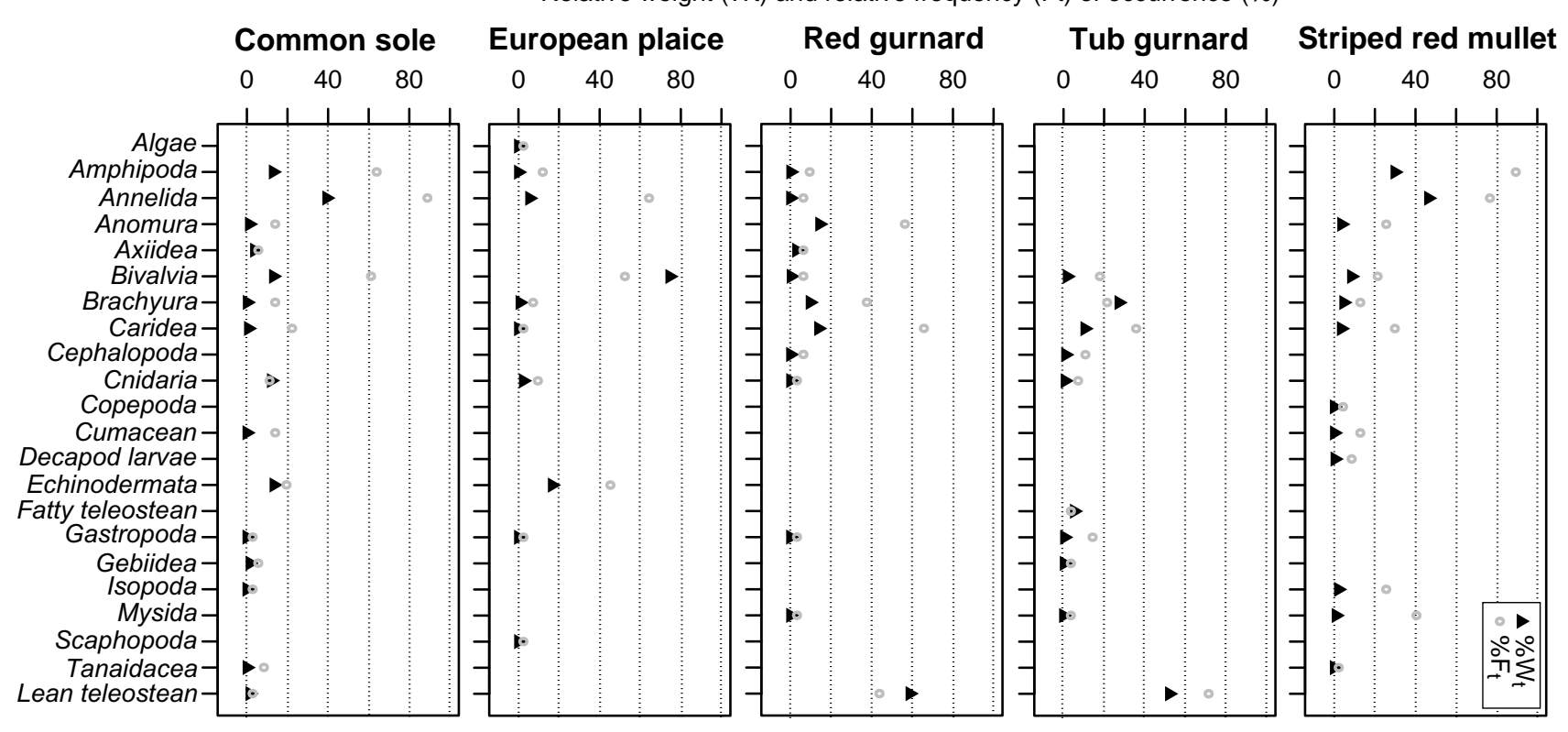


A. Global relationship between diet and otolith shape (model 1)

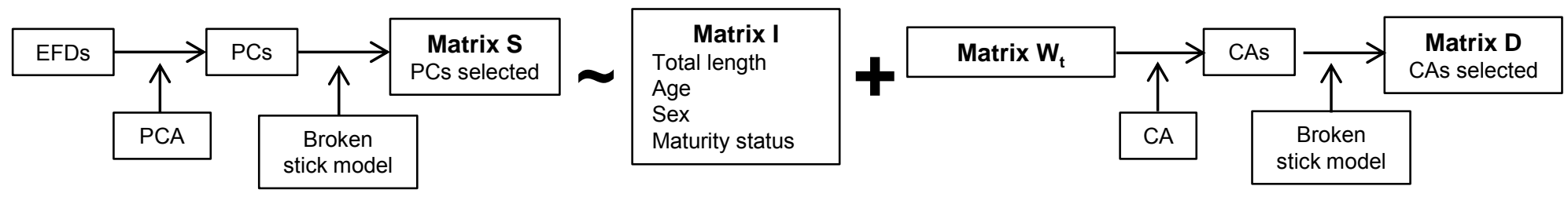

B. Taxonomic prey categories involved in the relationship between diet and otolith shape (model 2)

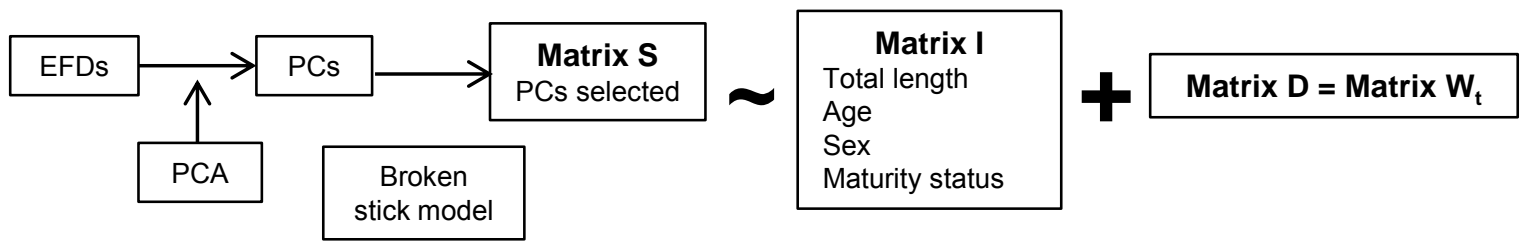

C. Contribution of diet relative composition vs food quantity to diet-otolith shape co-variation (model 3)

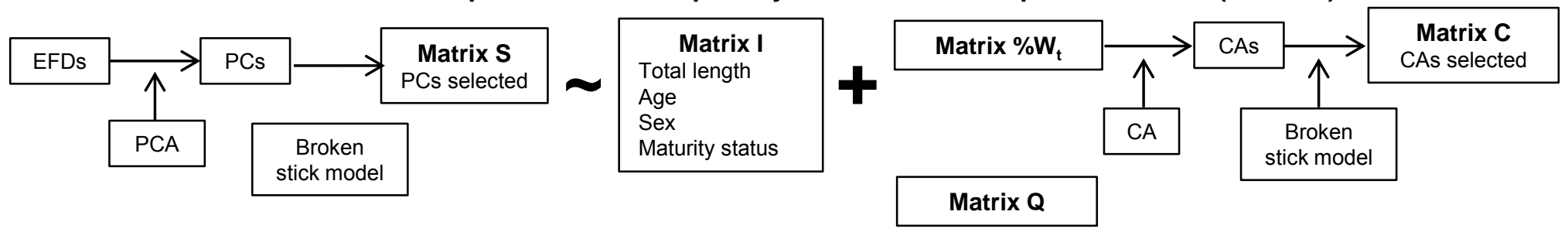

D. Relationship between diet energy composition and otolith shape (model 4)

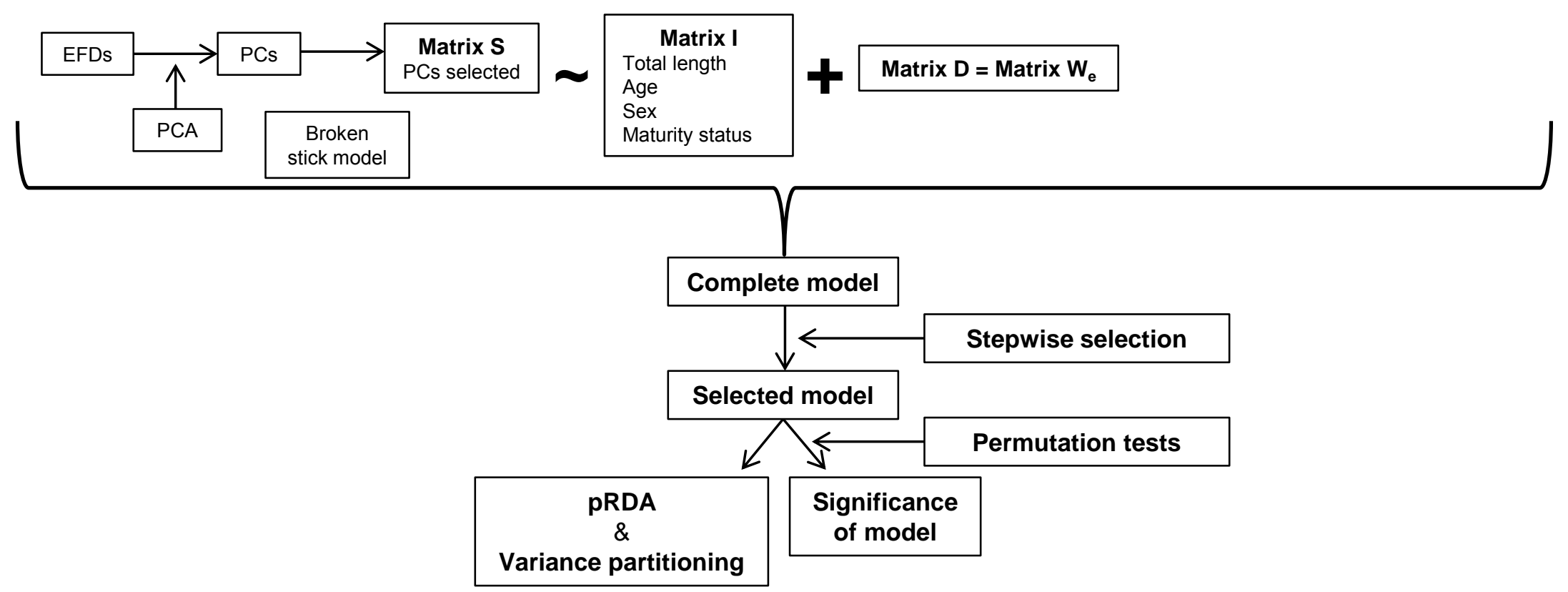


Global relationship between diet and otolith shape
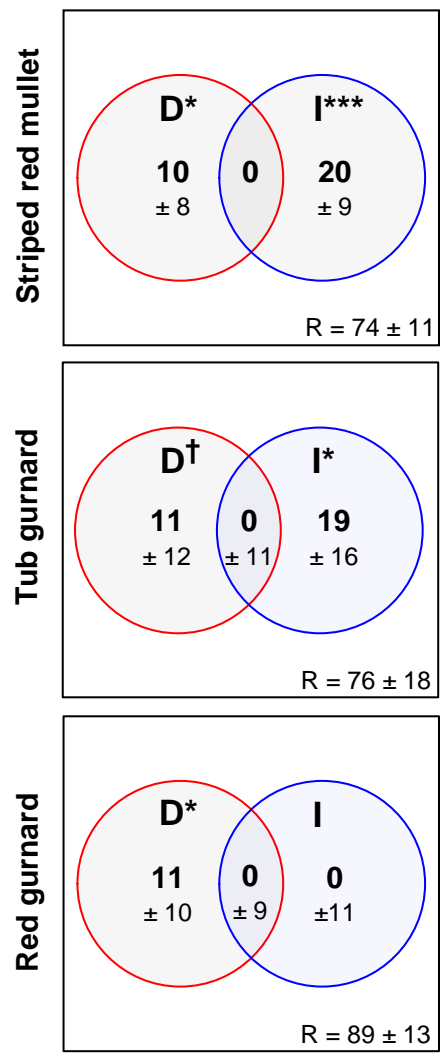

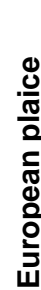

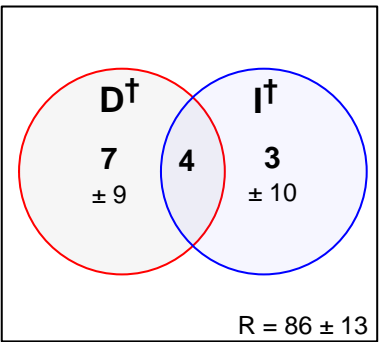

है
Taxonomic prey categories

involved in the relationship between diet and otolith shape to diet-otolith shape co-variation

Contribution of diet relative composition vs food quantity
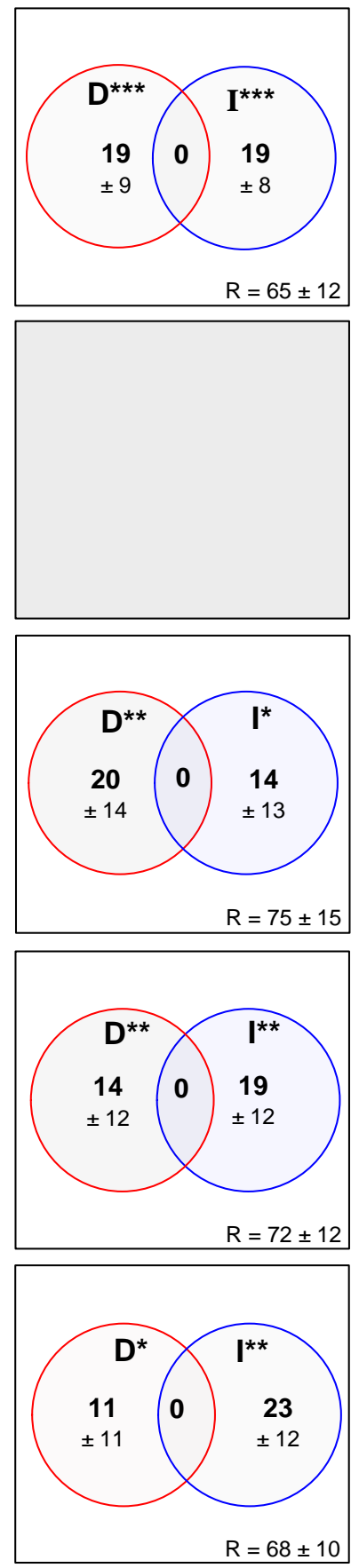
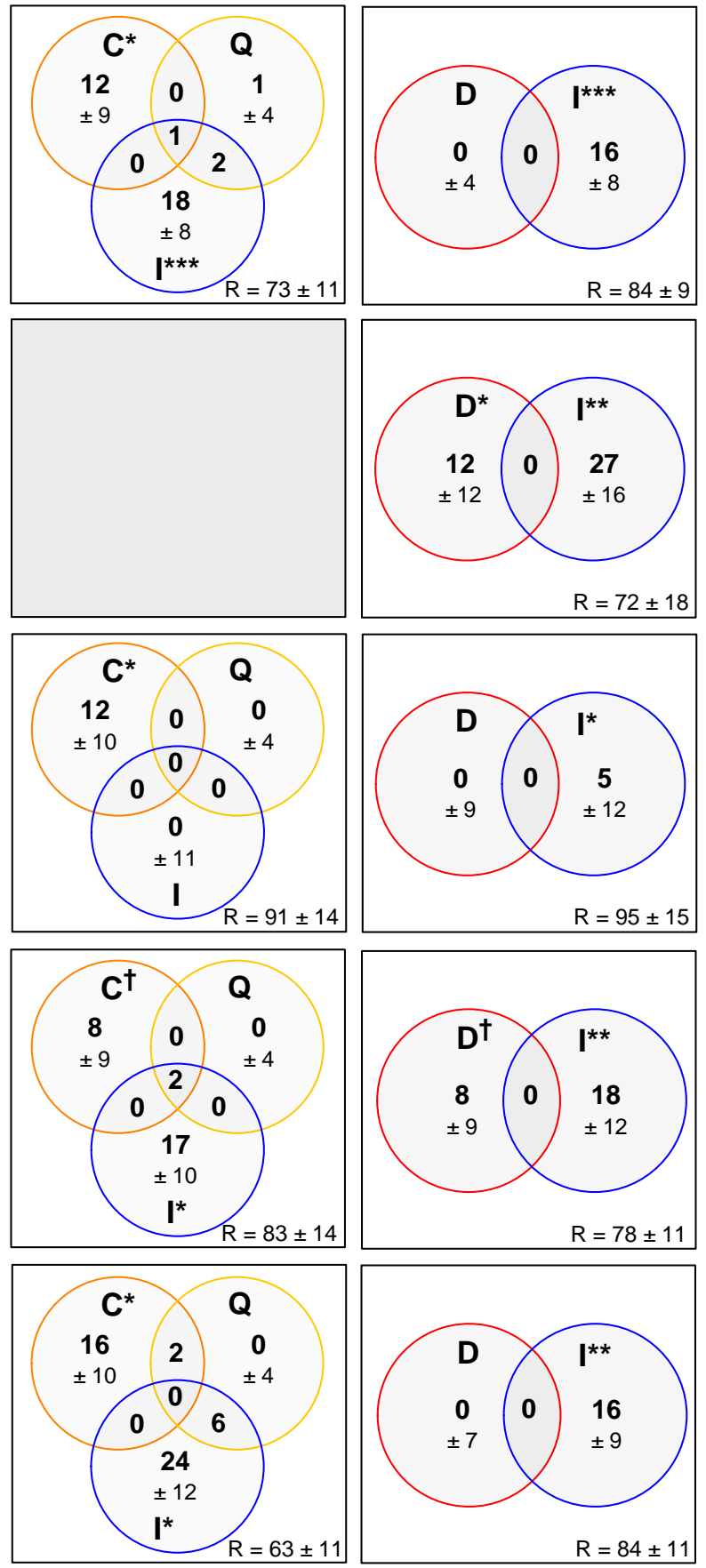

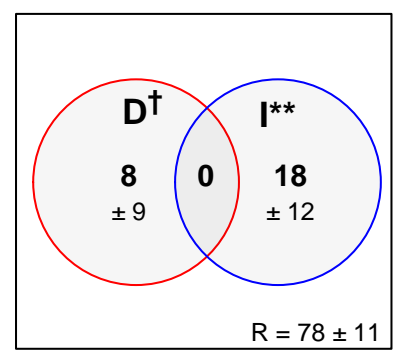

Relationship between diet energy composition and otolith shape
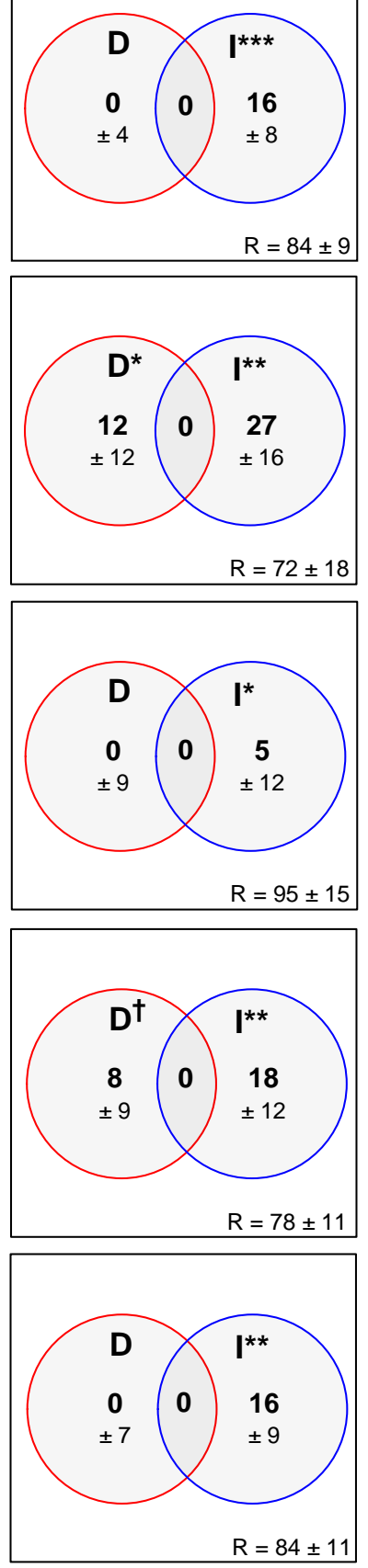
Taxonomic prey categories involved in the relationship diet and otolith shape

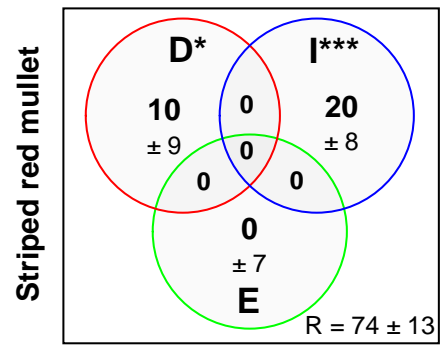

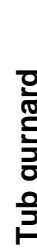

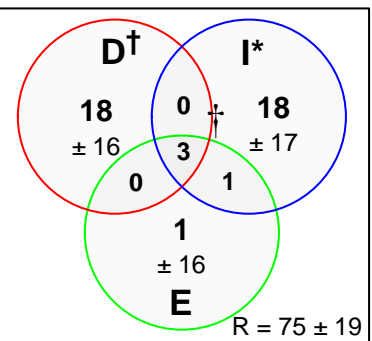

$\frac{2}{\frac{2}{0}}$

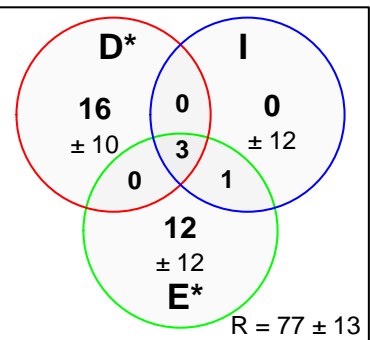

$\frac{0}{\frac{0}{0}}$

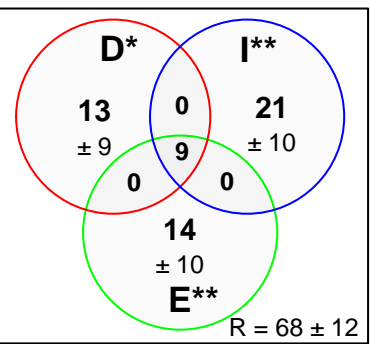

ơ

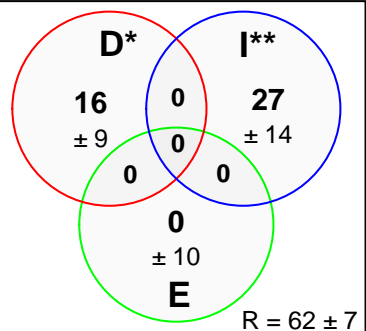
between diet and otolith shape to diet-otolith shape co-variation
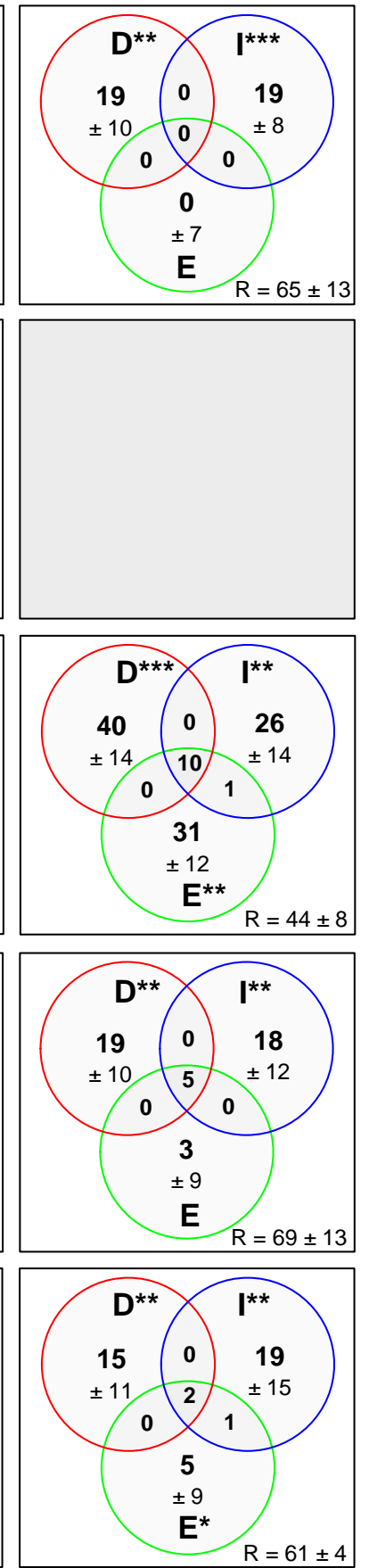

Contribution of diet relative composition vs food quantity

Relationship between diet energy composition and otolith shape
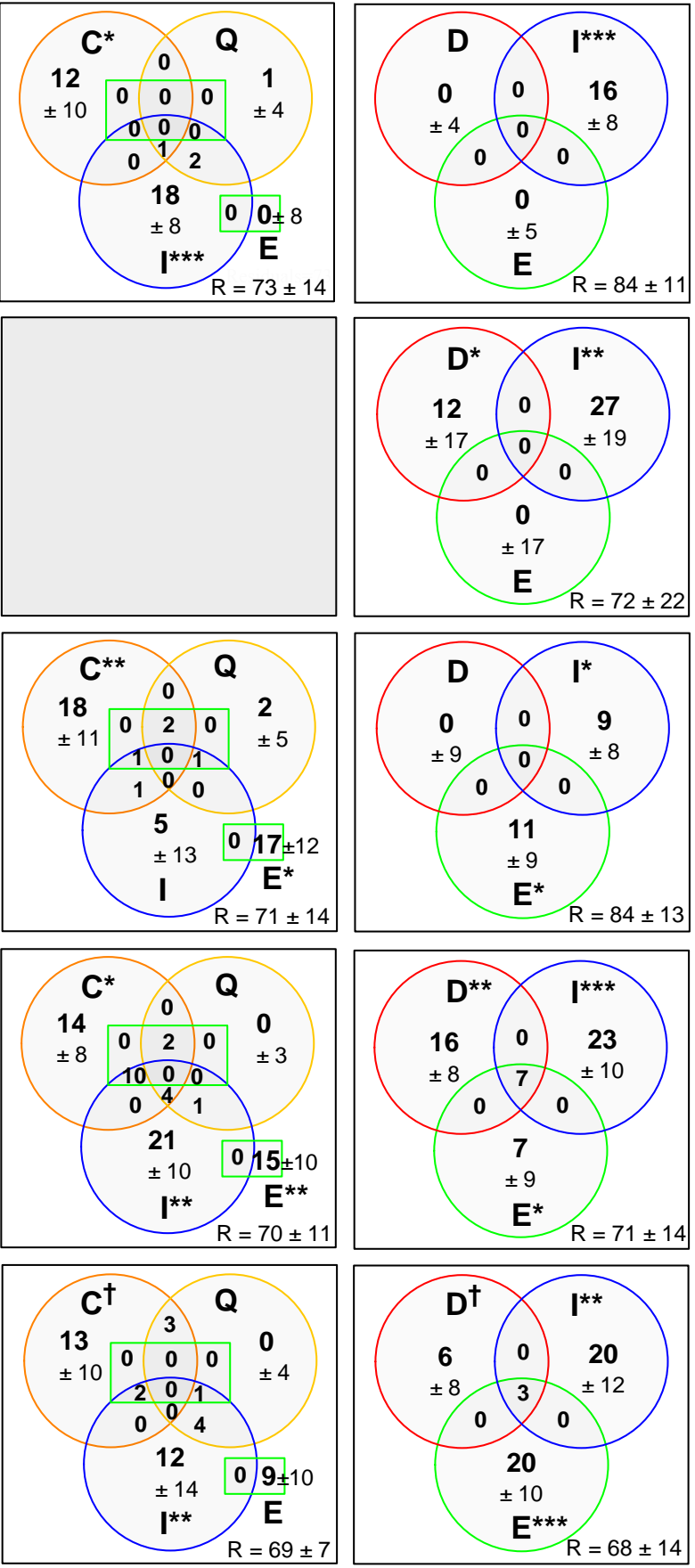
Table 1. Characteristics of the samples studied. Number of samples analyzed ( $\boldsymbol{N})$, number of females $\left(N_{F}\right)$, number of males $\left(N_{M}\right)$, number of individuals with undetermined sex ( $N_{U}$ ), proportion of mature individuals (\% Mat), age and total length distributions of the samples.

\begin{tabular}{|c|c|c|c|c|c|}
\hline Species & $N$ & $N_{F} / N_{M} / N_{U}$ & \% Mat & $\begin{array}{c}\text { Age (years) } \\
\text { Mean } \pm \text { SD } \\
\text { Min-Max }\end{array}$ & $\begin{array}{c}\text { Total length }(\mathrm{cm}) \\
\text { Mean } \pm \text { SD } \\
\text { Min-Max }\end{array}$ \\
\hline Striped red mullet & 47 & $08 / 16 / 23$ & 48.94 & $\begin{array}{c}0.62 \pm 0.79 \\
0-3\end{array}$ & $\begin{array}{c}16.51 \pm 5.60 \\
9-32\end{array}$ \\
\hline Tub gurnard & 28 & $10 / 18 / 00$ & 32.14 & $\begin{array}{c}1.75 \pm 0.84 \\
0-3\end{array}$ & $\begin{array}{c}25.86 \pm 6.61 \\
16-40\end{array}$ \\
\hline Red gurnard & 32 & $12 / 19 / 01$ & 37.50 & $\begin{array}{c}2.69 \pm 0.74 \\
1-4\end{array}$ & $\begin{array}{c}24.91 \pm 2.85 \\
20-31\end{array}$ \\
\hline European plaice & 42 & $26 / 14 / 02$ & 76.19 & $\begin{array}{c}1.81 \pm 1.38 \\
0-7\end{array}$ & $\begin{array}{c}27.33 \pm 7.45 \\
9-43\end{array}$ \\
\hline Common sole & 36 & $18 / 17 / 01$ & 91.67 & $\begin{array}{c}2.44 \pm 1.61 \\
1-6\end{array}$ & $\begin{array}{c}25.94 \pm 5.81 \\
17-38\end{array}$ \\
\hline
\end{tabular}


Table 2. Results of the three RDA models (as detailed in figure 3) for the five studied fish species. "Otolith shape" gives the number of principal components (N PCs) in the response matrix $\mathbf{S}$ used to describe otolith shape and the percentage of variance in Elliptical Fourier Descriptors they explain (\%). "Individual" and "Diet" correspond to explanatory matrices I , and D in reduced models. More precisely, "Individual" gives the selected individual-state variables. "Diet" indicates the variables the matrix $\mathbf{D}$, i.e. the number of correspondence axes (N CAs) and the percentage of variance they explain (\%) in diet composition $\mathbf{W}_{t}$ and relative diet composition $\% W_{t, j}$ in models 1 and 3, respectively, and the selected prey categories in models 2 and 4 . "Model selected" gives the degrees of freedom (df), the F statistic, the corresponding P-value and the percentage of variation explained (\%) by the reduced model.

\begin{tabular}{|c|c|c|c|c|c|c|c|c|c|}
\hline \multirow[t]{2}{*}{ Specie } & \multicolumn{2}{|c|}{ Otolith shape $S$} & \multirow[t]{2}{*}{ Individual I } & \multicolumn{2}{|c|}{ Diet D } & \multicolumn{4}{|c|}{ Model selected } \\
\hline & N PCs & $\%$ & & & & $\mathrm{df}$ & $\mathrm{F}$ & P-value & $\%$ \\
\hline \multicolumn{4}{|c|}{$\begin{array}{l}\text { Global relationship between diet and otolith shape } \\
\text { (model 1) }\end{array}$} & N CAs & $\%$ & & & & \\
\hline Striped red mullet & 4 & 77.00 & $\begin{array}{l}\text { Size } \\
\text { Sex }\end{array}$ & 10 & 99.85 & 13 & 2.22 & 0.002 & 25.61 \\
\hline Tub gurnard & 2 & 70.18 & $\begin{array}{l}\text { Age } \\
\text { Sex }\end{array}$ & 4 & 90.59 & 8 & 2.06 & 0.016 & 23.95 \\
\hline Red gurnard & 3 & 77.84 & - & 4 & 94.01 & 4 & 1.97 & 0.039 & 11.11 \\
\hline European plaice & 3 & 74.02 & Maturity & 4 & 93.53 & 5 & 2.29 & 0.011 & 13.56 \\
\hline Common sole & 3 & 78.23 & $\begin{array}{l}\text { Age } \\
\text { Size } \\
\text { Sex }\end{array}$ & 8 & 95.32 & 16 & 2.31 & 0.003 & 37.50 \\
\hline \multicolumn{4}{|c|}{$\begin{array}{l}\text { Taxonomic prey categories involved in the } \\
\text { relationship between diet and otolith shape (model } 2 \text { ) }\end{array}$} & \multicolumn{2}{|c|}{$\begin{array}{c}\begin{array}{c}\text { Taxonomic prey } \\
\text { category }\end{array} \\
\end{array}$} & & & & \\
\hline Striped red mullet & 4 & 77.00 & $\begin{array}{l}\text { Size } \\
\text { Sex }\end{array}$ & $\begin{array}{r}\text { Annelid } \\
\text { Bivalvic } \\
\text { Caride } \\
\text { larva } \\
\end{array}$ & $\begin{array}{l}\text { Anomura, } \\
\text { 3rachyura, } \\
\text { Decapod } \\
\text { sopoda }\end{array}$ & 10 & 3.49 & 0.001 & 35.11 \\
\hline Tub gurnard & 2 & 70.18 & - & & 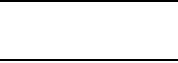 & - & - & - & 00.00 \\
\hline Red gurnard & 3 & 77.84 & $\begin{array}{c}\text { Age } \\
\text { Maturity }\end{array}$ & $\begin{array}{r}\text { Am } \\
\text { Gastrop }\end{array}$ & $\begin{array}{l}\text { ipoda, } \\
\text { a, Caridea }\end{array}$ & 7 & 2.51 & 0.003 & 25.40 \\
\hline European plaice & 3 & 74.02 & Age & $\begin{aligned} \mathrm{Am} \\
\text { Echir }\end{aligned}$ & ipoda, & 8 & 2.94 & 0.004 & 27.51 \\
\hline Common sole & 3 & 78.23 & $\begin{array}{l}\text { Age } \\
\text { Size }\end{array}$ & $\begin{array}{r}\text { Anomu } \\
\mathrm{G}\end{array}$ & $\begin{array}{l}\text { Cnidaria, } \\
\text { idea }\end{array}$ & 11 & 2.64 & 0.002 & 34.05 \\
\hline
\end{tabular}




\begin{tabular}{|c|c|c|c|c|c|c|c|c|c|}
\hline \multirow{2}{*}{\multicolumn{4}{|c|}{\begin{tabular}{l|c|} 
& Sex \\
Contribution of diet relative composition $v$ s food \\
quantity to diet-otolith shape co-variation (model 3$)$
\end{tabular}}} & \multirow{3}{*}{$\begin{array}{c}\text { N CAs } \\
10\end{array}$} & \multirow{3}{*}{$\%$} & \multirow{3}{*}{\multicolumn{2}{|c|}{$14 \quad 2.19$}} & \multirow[b]{3}{*}{0.001} & \multirow[b]{3}{*}{26.66} \\
\hline & & & & & & & & & \\
\hline Striped red mullet & 4 & 77.00 & $\begin{array}{l}\text { Size } \\
\text { Sex }\end{array}$ & & & & & & \\
\hline Tub gurnard & 2 & 70.18 & - & - & - & - & - & - & 00.00 \\
\hline Red gurnard & 3 & 77.84 & - & 4 & 94.23 & & 1.61 & 0.012 & 9.02 \\
\hline European plaice & 3 & 74.02 & Age & 4 & 92.64 & & 2.12 & 0.005 & 30.44 \\
\hline Common sole & 3 & 78.23 & $\begin{array}{l}\text { Age } \\
\text { Size } \\
\text { Sex }\end{array}$ & 9 & 96.78 & & 2.12 & 0.01 & 36.54 \\
\hline \multicolumn{4}{|c|}{$\begin{array}{l}\text { Relationship between diet energy composition and } \\
\text { otolith shape (model 4) }\end{array}$} & \multicolumn{2}{|c|}{$\begin{array}{l}\text { Energetic prey } \\
\text { category }\end{array}$} & & & & \\
\hline Striped red mullet & 4 & 77.00 & $\begin{array}{l}\text { Size } \\
\text { Sex }\end{array}$ & & & & 3.94 & 0.001 & 16.09 \\
\hline Tub gurnard & 2 & 70.18 & $\begin{array}{l}\text { Age } \\
\text { Size }\end{array}$ & low $/ \mathrm{n}$ & um/high & 7 & 2.53 & 0.003 & 28.45 \\
\hline Red gurnard & 3 & 77.84 & Size & & & 1 & 2.53 & 0.047 & 4.70 \\
\hline European plaice & 3 & 74.02 & Age & low $/ \mathrm{n}$ & um/high & 9 & 2.27 & 0.014 & 21.76 \\
\hline Common sole & 3 & 78.23 & Age & & & 5 & 2.38 & 0.007 & 16.43 \\
\hline
\end{tabular}


Table 3. Percent contribution with bootstrapped standard deviation of the diet matrix (D), the individual matrix (I) and residuals (R), obtained from variation partitioning performed on the reduced model for the four questions investigated and each studied species

\begin{tabular}{|c|c|c|c|c|c|c|c|c|}
\hline \multicolumn{9}{|c|}{ Global relationship between diet and otolith shape (model 1) } \\
\hline Species & \multicolumn{2}{|c|}{ D } & \multicolumn{2}{|c|}{ D\&I } & \multicolumn{2}{|c|}{$\mathbf{I}$} & \multicolumn{2}{|c|}{$\mathbf{R}$} \\
\hline Striped red mullet & \multicolumn{2}{|c|}{$10 \pm 8.29$} & \multicolumn{2}{|c|}{$0 \pm 7.31$} & \multicolumn{2}{|c|}{$20 \pm 8.51$} & \multicolumn{2}{|c|}{$74 \pm 10.94$} \\
\hline Tub gurnard & \multicolumn{2}{|c|}{$11 \pm 11.73$} & \multicolumn{2}{|c|}{$0 \pm 8.66$} & \multicolumn{2}{|c|}{$19 \pm 15.72$} & \multicolumn{2}{|c|}{$76 \pm 17.54$} \\
\hline Red gurnard & \multicolumn{2}{|c|}{$11 \pm 9.71$} & \multicolumn{2}{|c|}{$0 \pm 9.44$} & \multicolumn{2}{|c|}{$0 \pm 11.30$} & \multicolumn{2}{|c|}{$89 \pm 13.26$} \\
\hline European plaice & \multicolumn{2}{|c|}{$7 \pm 9.09$} & \multicolumn{2}{|c|}{$4 \pm 9.54$} & \multicolumn{2}{|c|}{$3 \pm 10.18$} & \multicolumn{2}{|c|}{$86 \pm 12.95$} \\
\hline Common sole & \multicolumn{2}{|c|}{$16 \pm 10.28$} & \multicolumn{2}{|c|}{$0 \pm 11.37$} & \multicolumn{2}{|c|}{$27 \pm 11.26$} & \multicolumn{2}{|c|}{$62 \pm 9.69$} \\
\hline \multicolumn{9}{|c|}{ Taxonomic prey categories involved in the relationship between diet and otolith shape (model 2) } \\
\hline Species & \multicolumn{2}{|c|}{ D } & \multicolumn{2}{|c|}{ D\&I } & \multicolumn{2}{|c|}{ I } & \multicolumn{2}{|c|}{$\mathbf{R}$} \\
\hline Striped red mullet & \multicolumn{2}{|c|}{$19 \pm 9.30$} & $0 \pm$ & & $19 \pm$ & 8.05 & $65 \pm$ & $=11.64$ \\
\hline Tub gurnard & & & & & & & & \\
\hline Red gurnard & $20 \pm$ & 3.98 & $0 \pm 1$ & .25 & $14 \pm$ & 2.76 & $75 \pm$ & $=14.52$ \\
\hline European plaice & $14 \pm$ & 2.41 & $0 \pm 1$ & .29 & $19 \pm$ & 2.20 & $72 \pm$ & $=11.95$ \\
\hline Common sole & $11 \pm$ & 1.30 & $0 \pm 1$ & 4.15 & $23 \pm$ & 1.93 & $68 \pm$ & 10.12 \\
\hline Contribution of $\mathrm{di}$ & t relative & ompositic & $v s$ food qu & antity to c & et-otolith & hape co- & ariation ( 1 & nodel 3) \\
\hline Species & $\mathbf{C}$ & $\mathbf{Q}$ & I & C\&Q & Q\&I & C\&I & C\&Q\&I & $\mathbf{R}$ \\
\hline Striped red mullet & $12 \pm 9.46$ & $1 \pm 3.54$ & $18 \pm 7.78$ & $0 \pm 3.44$ & $2 \pm 4.89$ & $0 \pm 7.07$ & $1 \pm 5.54$ & $73 \pm 11.39$ \\
\hline Tub gurnard & & & & & & & & \\
\hline Red gurnard & $\begin{array}{c}12 \pm \\
10.04\end{array}$ & $0 \pm 4.05$ & $0 \pm 11.39$ & $0 \pm 3.88$ & $0 \pm 4.31$ & $\begin{array}{c}0 \pm \\
10.09\end{array}$ & $0 \pm 4.20$ & $91 \pm 13.72$ \\
\hline European plaice & $8 \pm 8.68$ & $0 \pm 3.86$ & $\begin{array}{c}17 \pm \\
10.47\end{array}$ & $0 \pm 4.45$ & $0 \pm 3.93$ & $\begin{array}{c}0 \pm \\
10.12\end{array}$ & $2 \pm 4.75$ & $83 \pm 13.53$ \\
\hline Common sole & $\begin{array}{c}16 \pm \\
10.50 \\
\end{array}$ & $0 \pm 4.31$ & $\begin{array}{c}24 \pm \\
12.10 \\
\end{array}$ & $2 \pm 5.34$ & $6 \pm 6.55$ & $\begin{array}{c}0 \pm \\
11.90 \\
\end{array}$ & $0 \pm 7.05$ & $63 \pm 11.49$ \\
\hline Relation & $\mathbf{a d i e t} \mathrm{e}$ & 101 & ition and & (0)11 & (moder & & & \\
\hline Species & I & & D & & 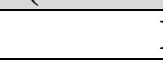 & & & $\mathbf{R}$ \\
\hline Striped red mullet & $0 \pm$ & & $0 \pm$ & & $16 \pm$ & 7.67 & $84=$ & \pm 8.84 \\
\hline Tub gurnard & $12 \pm$ & 1.73 & $0 \pm$ & & $27 \pm$ & 5.72 & $72 \pm$ & $=17.54$ \\
\hline Red gurnard & $0 \pm$ & & $0 \pm$ & & $5 \pm 1$ & 1.78 & $95 \pm$ & 15.01 \\
\hline European plaice & $8 \pm$ & & $0 \pm$ & & $18 \pm$ & 1.54 & $78 \pm$ & $=11.10$ \\
\hline Common sole & $0 \pm$ & & $0 \pm$ & & $16 \pm$ & 9.00 & $84 \pm$ & $=11.08$ \\
\hline
\end{tabular}


Table S1: Prey items found in the stomach contents of the studied species and the corresponding prey categories based on taxonomy (Taxonomic prey category) and on their energy content (Energetic prey category). References used to categorize preys in terms of energetic content are also given. When the energetic value of the prey item was not found, the energetic value of a closer taxon was used.

\begin{tabular}{|c|c|c|c|}
\hline Prey item & $\begin{array}{c}\text { Taxonomic prey } \\
\text { category }\end{array}$ & $\begin{array}{c}\text { Energetic prey } \\
\text { category }\end{array}$ & Reference \\
\hline Algae & Algae & Low & \\
\hline Amphipoda & Amphipoda & High & \begin{tabular}{|l} 
Dauvin \& Joncourt 1989 \\
Steimle \& Terranova 1985
\end{tabular} \\
\hline Aphroditidae & Annelida & High & Dauvin \& Joncourt 1989 \\
\hline Opheliidae & Annelida & High & Dauvin \& Joncourt 1989 \\
\hline Nereidae & Annelida & High & Dauvin \& Joncourt 1989 \\
\hline Glyceridae & Annelida & High & Dauvin \& Joncourt 1989 \\
\hline Glycera sp & Annelida & High & Dauvin \& Joncourt 1989 \\
\hline Phyllodocida & Annelida & High & Dauvin \& Joncourt 1989 \\
\hline Eunicidae & Annelida & High & Dauvin \& Joncourt 1989 \\
\hline Nephtyidae & Annelida & High & $\begin{array}{l}\text { Dauvin \& Joncourt } 1989 \\
\text { Steimle \& Terranova } 1985\end{array}$ \\
\hline Spionidae & Annelida & Medium & Dauvin \& Joncourt 1989 \\
\hline Chloraemidae & Annelida & Medium & Dauvin \& Joncourt 1989 \\
\hline Pectinariidae & Annelida & Medium & Dauvin \& Joncourt 1989 \\
\hline Pectinaria koreni & Annelida & Medium & Dauvin \& Joncourt 1989 \\
\hline Terebellidae & Annelida & Medium & $\begin{array}{l}\text { Dauvin \& Joncourt } 1989 \\
\text { Steimle \& Terranova } 1985\end{array}$ \\
\hline Lanice conchilega & Annelida & Medium & Dauvin \& Joncourt 1989 \\
\hline Arenicolidae & Annelida & Medium & Dauvin \& Joncourt 1989 \\
\hline Galatheoidea & Anomura & Low & Norrbin \& Båmstedt 1984 \\
\hline Galathea intermedia & Anomura & Low & Norrbin \& Båmstedt 1984 \\
\hline Pisidia longicornis & Anomura & Low & Norrbin \& Båmstedt 1984 \\
\hline Porcellana platycheles & Anomura & Low & Norrbin \& Båmstedt 1984 \\
\hline Porcellana sp & Anomura & Low & Norrbin \& Båmstedt 1984 \\
\hline Paguroidea & Anomura & High & $\begin{array}{l}\text { Dauvin \& Joncourt } 1989 \\
\text { Steimle \& Terranova } 1985\end{array}$ \\
\hline Pagurus bernhardus & Anomura & High & $\begin{array}{l}\text { Dauvin \& Joncourt } 1989 \\
\text { Steimle \& Terranova } 1985\end{array}$ \\
\hline Diogenes pugilator & Anomura & High & $\begin{array}{l}\text { Dauvin \& Joncourt } 1989 \\
\text { Steimle \& Terranova } 1985\end{array}$ \\
\hline Axiidea & Axiidea & Low & Norrbin \& Båmstedt 1984 \\
\hline Mytilidae & Bivalvia & Medium & $\begin{array}{l}\text { Dauvin \& Joncourt } 1989 \\
\text { Steimle \& Terranova } 1985\end{array}$ \\
\hline Mytilus edulis & Bivalvia & Medium & $\begin{array}{l}\text { Dauvin \& Joncourt } 1989 \\
\text { Steimle \& Terranova } 1985\end{array}$ \\
\hline Mactridae & Bivalvia & Medium & $\begin{array}{l}\text { Dauvin \& Joncourt } 1989 \\
\text { Steimle \& Terranova } 1985\end{array}$ \\
\hline Arcidae & Bivalvia & Medium & $\begin{array}{l}\text { Dauvin \& Joncourt } 1989 \\
\text { Steimle \& Terranova } 1985\end{array}$ \\
\hline Arca tetragona & Bivalvia & Medium & $\begin{array}{l}\text { Dauvin \& Joncourt } 1989 \\
\text { Steimle \& Terranova } 1985\end{array}$ \\
\hline Nuculidae & Bivalvia & Medium & Steimle \& Terranova 1985 \\
\hline Nucula sp & Bivalvia & Medium & Steimle \& Terranova 1985 \\
\hline Solenidae & Bivalvia & Medium & $\begin{array}{l}\text { Dauvin \& Joncourt } 1989 \\
\text { Steimle \& Terranova } 1985\end{array}$ \\
\hline Phaxas pellucidus & Bivalvia & Medium & $\begin{array}{l}\text { Dauvin \& Joncourt } 1989 \\
\text { Steimle \& Terranova } 1985\end{array}$ \\
\hline Ensis sp & Bivalvia & Medium & Steimle \& Terranova 1985 \\
\hline Semelidae & Bivalvia & Medium & $\begin{array}{l}\text { Dauvin \& Joncourt } 1989 \\
\text { Steimle \& Terranova } 1985\end{array}$ \\
\hline
\end{tabular}




\begin{tabular}{|c|c|c|c|}
\hline Abra alba & Bivalvia & Medium & Dauvin \& Joncourt 1989 \\
\hline Cardiidae & Bivalvia & Medium & $\begin{array}{l}\text { Dauvin \& Joncourt } 1989 \\
\text { Steimle \& Terranova } 1985\end{array}$ \\
\hline Parvicardium sp & Bivalvia & Medium & $\begin{array}{l}\text { Dauvin \& Joncourt } 1989 \\
\text { Steimle \& Terranova } 1985\end{array}$ \\
\hline Solecurtidae & Bivalvia & Medium & $\begin{array}{l}\text { Dauvin \& Joncourt } 1989 \\
\text { Steimle \& Terranova } 1985\end{array}$ \\
\hline Azorinus chamasolen & Bivalvia & Medium & $\begin{array}{l}\text { Dauvin \& Joncourt } 1989 \\
\text { Steimle \& Terranova } 1985\end{array}$ \\
\hline Donacidae & Bivalvia & Medium & $\begin{array}{l}\text { Dauvin \& Joncourt } 1989 \\
\text { Steimle \& Terranova } 1985\end{array}$ \\
\hline Donax vittatus & Bivalvia & Medium & $\begin{array}{l}\text { Dauvin \& Joncourt } 1989 \\
\text { Steimle \& Terranova } 1985\end{array}$ \\
\hline Pectinidae & Bivalvia & Medium & $\begin{array}{l}\text { Dauvin \& Joncourt } 1989 \\
\text { Steimle \& Terranova } 1985\end{array}$ \\
\hline Mimachlamys varia & Bivalvia & Medium & $\begin{array}{l}\text { Dauvin \& Joncourt } 1989 \\
\text { Steimle \& Terranova } 1985\end{array}$ \\
\hline Portunidae & Brachyura & High & Spitz et al. 2010 \\
\hline Liocarcinus sp & Brachyura & High & Dauvin \& Joncourt 1989 \\
\hline Liocarcinus depurator & Brachyura & High & Dauvin \& Joncourt 1989 \\
\hline Liocarcinus pusillus & Brachyura & High & Dauvin \& Joncourt 1989 \\
\hline Leucosiidae & Brachyura & Low & $\begin{array}{l}\text { Dauvin \& Joncourt } 1989 \\
\text { Steimle \& Terranova } 1985\end{array}$ \\
\hline Ebalia cranchii & Brachyura & Low & $\begin{array}{l}\text { Dauvin \& Joncourt } 1989 \\
\text { Steimle \& Terranova } 1985\end{array}$ \\
\hline Pinnotheridae & Brachyura & Low & $\begin{array}{l}\text { Dauvin \& Joncourt } 1989 \\
\text { Steimle \& Terranova } 1985\end{array}$ \\
\hline Pinnotheres pisum & Brachyura & Low & Dauvin \& Joncourt 1989 \\
\hline Thiinae & Brachyura & Low & $\begin{array}{l}\text { Dauvin \& Joncourt } 1989 \\
\text { Steimle \& Terranova } 1985\end{array}$ \\
\hline Thia scutellata & Brachyura & Low & $\begin{array}{l}\text { Dauvin \& Joncourt } 1989 \\
\text { Steimle \& Terranova } 1985\end{array}$ \\
\hline Atelecyclidae & Brachyura & Low & $\begin{array}{l}\text { Dauvin \& Joncourt } 1989 \\
\text { Steimle \& Terranova } 1985\end{array}$ \\
\hline Inachidea & Brachyura & Low & $\begin{array}{l}\text { Dauvin \& Joncourt } 1989 \\
\text { Steimle \& Terranova } 1985\end{array}$ \\
\hline Macropodia rostrata & Brachyura & Low & $\begin{array}{l}\text { Dauvin \& Joncourt } 1989 \\
\text { Steimle \& Terranova } 1985\end{array}$ \\
\hline Inachus dorsettentis & Brachyura & Low & $\begin{array}{l}\text { Dauvin \& Joncourt } 1989 \\
\text { Steimle \& Terranova } 1985\end{array}$ \\
\hline Crangonidae & Caridea & High & $\begin{array}{l}\text { Dauvin \& Joncourt } 1989 \\
\text { Spitz et al. } 2010\end{array}$ \\
\hline Crangon crangon & Caridea & High & $\begin{array}{l}\text { Dauvin \& Joncourt } 1989 \\
\text { Spitz et al. } 2010\end{array}$ \\
\hline Philocheras sp & Caridea & High & $\begin{array}{l}\text { Dauvin \& Joncourt } 1989 \\
\text { Spitz et al. } 2010\end{array}$ \\
\hline Philocheras fasciatus & Caridea & High & Dauvin \& Joncourt 1989 \\
\hline Philocheras sculptus & Caridea & High & Dauvin \& Joncourt 1989 \\
\hline Philocheras trispinosus & Caridea & High & Dauvin \& Joncourt 1989 \\
\hline Hippolytidae & Caridea & High & $\begin{array}{l}\text { Dauvin \& Joncourt } 1989 \\
\text { Spitz et al. } 2010\end{array}$ \\
\hline Hippolyte sp & Caridea & High & $\begin{array}{l}\text { Dauvin \& Joncourt } 1989 \\
\text { Spitz et al. } 2010\end{array}$ \\
\hline Eualus gaimardii & Caridea & High & $\begin{array}{l}\text { Dauvin \& Joncourt } 1989 \\
\text { Spitz et al. } 2010\end{array}$ \\
\hline Eualus occultus & Caridea & High & $\begin{array}{l}\text { Dauvin \& Joncourt } 1989 \\
\text { Spitz et al. } 2010\end{array}$ \\
\hline Processidae & Caridea & High & $\begin{array}{l}\text { Dauvin \& Joncourt } 1989 \\
\text { Spitz et al. } 2010\end{array}$ \\
\hline Processa sp & Caridea & High & $\begin{array}{l}\text { Dauvin \& Joncourt } 1989 \\
\text { Spitz et al. } 2010\end{array}$ \\
\hline Processa canaliculata & Caridea & High & $\begin{array}{l}\text { Dauvin \& Joncourt } 1989 \\
\text { Spitz et al. } 2010\end{array}$ \\
\hline
\end{tabular}




\begin{tabular}{|c|c|c|c|}
\hline Processa edulis & Caridea & High & $\begin{array}{l}\text { Dauvin \& Joncourt } 1989 \\
\text { Spitz et al. } 2010\end{array}$ \\
\hline pandalidae & Caridea & High & $\begin{array}{l}\text { Dauvin \& Joncourt } 1989 \\
\text { Spitz et al. } 2010\end{array}$ \\
\hline Pandalina brevirostris & Caridea & High & $\begin{array}{l}\text { Dauvin \& Joncourt } 1989 \\
\text { Spitz et al. } 2010\end{array}$ \\
\hline Palaemonidae & Caridea & High & Spitz et al. 2010 \\
\hline Palaemon sp & Caridea & High & Spitz et al. 2010 \\
\hline Sepiolidae & Cephalopoda & Medium & Spitz et al. 2010 \\
\hline Ommastrephidae & Cephalopoda & Medium & Spitz et al. 2010 \\
\hline Hydrozoa & Cnidaria & Low & Steimle \& Terranova 1985 \\
\hline Anthozoa & Cnidaria & Low & Steimle \& Terranova 1985 \\
\hline Copepoda & Copepoda & High & Norrbin \& Båmstedt 1984 \\
\hline Bodotriidae & Cumacean & High & Norrbin \& Båmstedt 1984 \\
\hline Bodotria sp & Cumacean & High & Norrbin \& Båmstedt 1984 \\
\hline Bodotria arenosa & Cumacean & High & Norrbin \& Båmstedt 1984 \\
\hline Bodotria scorpioides & Cumacean & High & Norrbin \& Båmstedt 1984 \\
\hline Vaunthompsonia sp & Cumacean & High & Norrbin \& Båmstedt 1984 \\
\hline Pseudocumatidae & Cumacean & High & Norrbin \& Båmstedt 1984 \\
\hline Pseudocuma sp & Cumacean & High & Norrbin \& Båmstedt 1984 \\
\hline Decapod larvae & Decapod larvae & High & Norrbin \& Båmstedt 1984 \\
\hline Echinozoa & Echinodermata & Low & $\begin{array}{l}\text { Dauvin \& Joncourt } 1989 \\
\text { Steimle \& Terranova } 1985\end{array}$ \\
\hline Echinocyamus pusillus & Echinodermata & Low & $\begin{array}{l}\text { Dauvin \& Joncourt } 1989 \\
\text { Steimle \& Terranova } 1985\end{array}$ \\
\hline Asterozoa & Echinodermata & Low & $\begin{array}{l}\text { Dauvin \& Joncourt } 1989 \\
\text { Steimle \& Terranova } 1985\end{array}$ \\
\hline Ophiutrix fragilis & Echinodermata & Low & Dauvin \& Joncourt 1989 \\
\hline Ophiuridae & Echinodermata & Low & Dauvin \& Joncourt 1989 \\
\hline Mullus surmuletus & Fatty teleostean & High & Spitz et al. 2010 \\
\hline Trachurus Trachurus & Fatty teleostean & High & Spitz et al. 2010 \\
\hline Naticidae & Gastropoda & Medium & Dauvin \& Joncourt 1989 \\
\hline Euspira sp & Gastropoda & Medium & Dauvin \& Joncourt 1989 \\
\hline Lacunidae & Gastropoda & Medium & Dauvin \& Joncourt 1989 \\
\hline Littorinidae & Gastropoda & Medium & Dauvin \& Joncourt 1989 \\
\hline Calyptraeidae & Gastropoda & Medium & Dauvin \& Joncourt 1989 \\
\hline Crepidula fornicata & Gastropoda & Medium & Dauvin \& Joncourt 1989 \\
\hline Buccinidae & Gastropoda & Medium & Dauvin \& Joncourt 1989 \\
\hline Gebiidea & Gebiidea & High & Norrbin \& Båmstedt 1984 \\
\hline Isopoda & Isopoda & High & Dauvin \& Joncourt 1989 \\
\hline Mysida & Mysida & High & Norrbin \& Båmstedt 1984 \\
\hline Scaphopoda & Scaphopoda & High & Dauvin \& Joncourt 1989 \\
\hline Upogebia deltaura & Tanaidacea & High & Dauvin \& Joncourt 1989 \\
\hline Perciformes & Lean teleostean & Medium & Spitz et al. 2010 \\
\hline Callionymus lyra & Lean teleostean & Medium & Spitz et al. 2010 \\
\hline Gobiidae & Lean teleostean & Medium & Spitz et al. 2010 \\
\hline Pleuronectiformes & Lean teleostean & Medium & Spitz et al. 2010 \\
\hline Solea Solea & Lean teleostean & Medium & Spitz et al. 2010 \\
\hline
\end{tabular}


Table S2. Results of the four RDA models (as detailed in figure 3) for the five studied fish species. "Otolith shape" gives the number of principal components (N PCs) in the response matrix $\mathbf{S}$ used to describe otolith shape and the percentage of variance in Elliptical Fourier Descriptors they explain (\%). "Environment", "Individual" and "Diet" correspond to explanatory matrices E, I , and D in reduced models. More precisely, "Environment" and "Individual" give the selected environmental and individual-state variables, respectively. "Diet" indicates the variables in the matrix $\mathbf{D}$, i.e. the number of correspondence axes ( $\mathrm{N} \mathrm{CAs)} \mathrm{and} \mathrm{the} \mathrm{percentage} \mathrm{of} \mathrm{variance} \mathrm{they} \mathrm{explain} \mathrm{( \% )} \mathrm{in} \mathrm{diet} \mathrm{composition} \mathbf{W}_{t}$ and relative diet composition $\% W_{t, j}$ in models 1 and 3 , respectively, and the selected prey categories in models 2 and 4. "Model selected" gives the degrees of freedom (df), the F statistic, the corresponding P-value and the percentage of variation explained (\%) by the reduced model.

\begin{tabular}{|c|c|c|c|c|c|c|c|c|c|c|}
\hline \multirow[t]{2}{*}{ Species } & \multicolumn{2}{|c|}{ Otolith shape $S$} & \multirow[t]{2}{*}{ Environment E } & \multirow[t]{2}{*}{ Individual I } & \multicolumn{2}{|c|}{ Diet D } & \multicolumn{4}{|c|}{ Model selected } \\
\hline & N PCs & $\%$ & & & & & $\mathrm{df}$ & $\mathrm{F}$ & P-value & $\%$ \\
\hline \multicolumn{5}{|c|}{ Global relationship between diet and otolith shape (model 1) } & N CAs & $\%$ & & & & \\
\hline Striped red mullet & 4 & 77 & - & $\begin{array}{l}\text { Size } \\
\text { Sex }\end{array}$ & 10 & 99.85 & 13 & 2.22 & 0.001 & 25.61 \\
\hline Tub gurnard & 2 & 70.18 & Longitude $\times$ Latitude & $\begin{array}{l}\text { Age } \\
\text { Sex }\end{array}$ & 4 & 90.59 & 11 & 1.83 & 0.041 & 25.31 \\
\hline Red gurnard & 3 & 77.84 & $\begin{array}{l}\text { Longitude } \times \text { Latitude } \\
\text { Temperature }\end{array}$ & & 4 & 94.01 & 8 & 2.15 & 0.007 & 22.89 \\
\hline European plaice & 3 & 74.02 & $\begin{array}{c}\text { Temperature } \\
\text { Salinity }\end{array}$ & $\begin{array}{c}\text { Age } \\
\text { Sex } \\
\text { Maturity }\end{array}$ & 4 & 93.53 & 15 & 2.28 & 0.001 & 31.94 \\
\hline Common sole & 3 & 78.23 & - & $\begin{array}{l}\text { Age } \\
\text { Size } \\
\text { Sex }\end{array}$ & 8 & 95.32 & 16 & 2.31 & 0.003 & 37.50 \\
\hline \multicolumn{5}{|c|}{$\begin{array}{l}\text { Taxonomic prey categories involved in the relationship between diet and } \\
\text { otolith shape (model 2) }\end{array}$} & \multicolumn{2}{|c|}{$\begin{array}{l}\text { Taxonomic prey } \\
\text { category }\end{array}$} & & & & \\
\hline Striped red mullet & 4 & 77 & - & $\begin{array}{l}\text { Size } \\
\text { Sex }\end{array}$ & $\begin{array}{r}\text { Annelic } \\
\text { Bivalvi } \\
\text { Caride } \\
\text { larva }\end{array}$ & $\begin{array}{l}\text { Anomura, } \\
\text { 3rachyura, } \\
\text { Decapod } \\
\text { Isopoda }\end{array}$ & 10 & 3.49 & 0.001 & 35.11 \\
\hline Tub gurnard & 2 & 70.18 & - & - & - & - & - & - & - & 00.00 \\
\hline Red gurnard & 3 & 77.84 & $\begin{array}{c}\text { Longitude } \times \text { Latitude } \\
\text { Temperature } \\
\text { Depth }\end{array}$ & $\begin{array}{c}\text { Size } \\
\text { Age } \\
\text { Maturity }\end{array}$ & $\begin{array}{r}\text { Anneli } \\
\mathrm{C} \\
\text { Cep }\end{array}$ & $\begin{array}{l}\text { Axiidea, } \\
\text { dea, } \\
\text { opoda, }\end{array}$ & 17 & 3.28 & 0.001 & 55.56 \\
\hline
\end{tabular}




\begin{tabular}{|c|c|c|c|c|c|c|c|c|c|c|}
\hline & & & & & \multicolumn{2}{|c|}{$\begin{array}{l}\text { Gastropoda, Mysida, } \\
\text { Teleostean }\end{array}$} & & & & \\
\hline European plaice & 3 & 74.02 & Depth & Age & \multicolumn{2}{|c|}{$\begin{array}{c}\text { Amphipoda, } \\
\text { Brachyura, } \\
\text { Echinodermata }\end{array}$} & 10 & 2.85 & 0.001 & 31.10 \\
\hline Common sole & 3 & 78.23 & Temperature & $\begin{array}{l}\text { Age } \\
\text { Size } \\
\text { Sex }\end{array}$ & \multicolumn{2}{|c|}{$\begin{array}{c}\text { Anomura, Caridea, } \\
\text { Cnidaria }\end{array}$} & 12 & 2.85 & 0.001 & 38.85 \\
\hline \multicolumn{5}{|c|}{$\begin{array}{l}\text { Contribution of diet relative composition vs food quantity to diet-otolith } \\
\text { shape co-variation (model 3) }\end{array}$} & N CAs & & & & & \\
\hline Striped red mullet & 4 & 77 & - & $\begin{array}{l}\text { Size } \\
\text { Sex } \\
\end{array}$ & 10 & 99.87 & 14 & 2.19 & 0.001 & 26.66 \\
\hline Tub gurnard & 2 & 70.18 & - & - & - & - & - & - & - & 00.00 \\
\hline Red gurnard & 3 & 77.84 & $\begin{array}{l}\text { Longitude } \times \text { Latitude } \\
\text { Temperature }\end{array}$ & Maturity & 4 & 94.23 & 10 & 2.24 & 0.004 & 28.63 \\
\hline European plaice & 3 & 74.02 & $\begin{array}{l}\text { Temperature } \\
\text { Salinity }\end{array}$ & $\begin{array}{c}\text { Age } \\
\text { Sex } \\
\text { Maturity } \\
\end{array}$ & 4 & 92.64 & 16 & 2.12 & 0.005 & 30.44 \\
\hline Common sole & 3 & 78.23 & $\begin{array}{c}\text { Temperature } \\
\text { Longitude } \times \text { Latitude }\end{array}$ & Size & 9 & 96.78 & 15 & 2.04 & 0.002 & 30.77 \\
\hline \multicolumn{5}{|c|}{ Relationship between diet energy composition and otolith shape (model 4) } & \multicolumn{2}{|c|}{$\begin{array}{l}\text { Energetic prey } \\
\text { category }\end{array}$} & & & & \\
\hline Striped red mullet & 4 & 77 & - & $\begin{array}{l}\text { Size } \\
\text { Sex }\end{array}$ & & & 3 & 3.94 & 0.001 & 16.09 \\
\hline Tub gurnard & 2 & 70.18 & - & $\begin{array}{l}\text { Age } \\
\text { Size }\end{array}$ & \multicolumn{2}{|c|}{ low/medium/high } & 7 & 2.53 & 0.003 & 28.45 \\
\hline Red gurnard & 3 & 77.84 & Longitude $\times$ Latitude & Size & & & 4 & 2.41 & 0.006 & 15.43 \\
\hline European plaice & 3 & 74.02 & $\begin{array}{l}\text { Salinity } \\
\text { Depth }\end{array}$ & Age & \multicolumn{2}{|c|}{ low/medium/high } & 11 & 2.51 & 0.004 & 28.80 \\
\hline Common sole & 3 & 78.23 & $\begin{array}{c}\text { Temperature } \\
\text { Longitude } \times \text { Latitude } \\
\text { Depth } \\
\end{array}$ & $\begin{array}{l}\text { Size } \\
\text { Sex }\end{array}$ & \multicolumn{2}{|c|}{ low/medium/high } & 11 & 2.51 & 0.001 & 32.20 \\
\hline
\end{tabular}


Table S3. Individual-state ( $\boldsymbol{A}:$ age, $L_{\mathbf{T}}$ : total length, $\boldsymbol{S e}:$ sex, $\boldsymbol{M}:$ maturity) variables acting on otolith shape according to the model and the species considered. For each effect kept in the model reduced by stepwise selection, the $F$ statistic (while respecting marginality of the effects, type 2 tests) is given together with the numerator degrees of freedom as exponent and the denominator degrees of freedom as index. The corresponding $P$-value is indicated by the following symbols: $<5 \% *,<1 \% * *,<0.1 \% * * *$.

\begin{tabular}{|c|c|c|c|c|}
\hline Species & $\boldsymbol{A}$ & $L_{\mathbf{T}}$ & Se & $M$ \\
\hline \multicolumn{5}{|c|}{ Global relationship between diet and otolith shape (model 1) } \\
\hline Striped red mullet & & $2.98 \frac{1}{33} *$ & $4.46_{33}^{2} * * *$ & \\
\hline Tub gurnard & $2.644_{18}^{3} *$ & & $5.67_{18}^{1}$ & \\
\hline \multicolumn{5}{|l|}{ Red gurnard } \\
\hline European plaice & $2.11{ }_{26}^{6} *$ & & $3.00 \frac{2}{26} *$ & $2.40 \frac{1}{26}$ \\
\hline Common sole & $2.30{ }_{19}^{5} *$ & $2.87{ }_{19}^{1} *$ & $2.45_{19}^{2} *$ & \\
\hline \multicolumn{5}{|c|}{ Prey categories involved in the relationship (model 2) } \\
\hline Striped red mullet & & $4.41 \frac{1}{36} *$ & $4.41 \frac{2}{36} * * *$ & \\
\hline \multicolumn{5}{|l|}{ Tub gurnard } \\
\hline Red gurnard & $1.30 \frac{3}{16}$ & $0.17_{16}^{1}$ & & $2.54{ }_{16}^{1}$ \\
\hline European plaice & $2.65 \frac{6}{31} * *$ & & & \\
\hline Common sole & $1.62 \frac{5}{26}$ & $3.13 \frac{1}{26} *$ & & \\
\hline \multicolumn{5}{|c|}{ Contribution of diet relative composition VS food quantity (model 3) } \\
\hline Striped red mullet & & $3.80 \frac{1}{32} * *$ & $4.38 \frac{2}{32} * * *$ & \\
\hline \multicolumn{5}{|l|}{ Tub gurnard } \\
\hline Red gurnard & & & & $1.98{ }_{23}^{1}$ \\
\hline European plaice & $2.02{ }_{25}^{6} *$ & & $3.01 \frac{2}{25} *$ & $2.58{ }_{25}^{1}$ \\
\hline Common sole & & $3.87 \frac{1}{22} *$ & & \\
\hline \multicolumn{5}{|c|}{ Relationship between diet energy composition and otolith shape (model 4) } \\
\hline Striped red mullet & & $3.47{ }_{43}^{1} *$ & $2.68{ }_{43}^{2} * *$ & \\
\hline Tub gurnard & $3.40 \frac{3}{20} * *$ & $4.03 \frac{1}{20} *$ & & \\
\hline Red gurnard & & $2.53 \frac{1}{30} *$ & & \\
\hline European plaice & $2.42 \frac{6}{32} *$ & & & \\
\hline Common sole & $2.38 \frac{5}{30} * *$ & & & \\
\hline
\end{tabular}

